\title{
A SYSTEMATIC REVIEW OF THE CLINICAL UTILITY OF THE CONCEPT OF SELF-DISGUST
}

\author{
Dr Aoife Clarke ${ }^{a}$ \\ Dr Jane Simpson ${ }^{\text {a* }}$ \\ Dr Filippo Varese ${ }^{\text {bc }}$
}

${ }_{*}^{*}$ Division of Health Research, Lancaster University, Lancaster, UK

$b *$ Division of Psychology and Mental Health, University of Manchester, Manchester, UK;

c* Complex Trauma and Resilience Research Unit, Greater Manchester Mental Health NHS Foundation Trust, Manchester Academic Health Science Centre, Manchester, UK

*Correspondence concerning this article should be addressed to Jane Simpson, Division of Health Research, c/o Furness Building, Fylde Avenue, Lancaster University, Lancaster, Lancashire, UK, LA1 4FY. E-mail:j.simpson2@lancaster.ac.uk. Tel: 44-1524 592858 


\section{Highlights}

- 31 papers on the topic of self-disgust were integrated and analysed.

- Self-disgust is consistently uniquely characterised by physical nausea and social withdrawal.

- Self-disgust is particularly implicated in PTSD, depression and eating disorders, supporting its conceptualisation as a transdiagnostic construct

- Research suggests that self-disgust has a predictive role in these difficulties. 


\section{Abstract}

This systematic literature review examined the clinical utility of the construct of selfdisgust in understanding mental distress. Specifically, the review assessed whether there is a shared conceptual definition of self-disgust, the face and construct validity of the quantitative assessment measures of self-disgust, and the predictive validity of self-disgust in formulating the development of a range of psychological difficulties. A systematic database search supplemented by manual searches of references and citations identified thirty-one relevant papers (27 quantitative, 3 qualitative, 1 mixed). Analysis of qualitative papers indicated a number of shared features in the definition of self-disgust, including a visceral sense of selfelicited nausea accompanied by social withdrawal and attempts at cleansing or suppressing aspects of the self. Quantitative assessment measures appeared to capture these dimensionand evidenced good psychometric properties, although some measures may have only partially captured the full self-disgust construct. Strong relationships were observed between selfdisgust and a range of mental health presentations, in particular depression, body-image difficulties, and trauma-related difficulties. However, these relationships are smaller when the effects of other negative self-referential emotions were controlled, and stronger conclusions 
about the predictive validity of self-disgust are limited by the cross-sectional nature of many of the studies. 
Key-words: Self-disgust; mental health; validity; utility; review

\section{Introduction}

Theoretical advances in understanding the relationship between cognition and emotion have underpinned important developments in clinical practice. To illustrate, the specification of emotion generation in response to events via both an associative route and via appraisals derived from organizing cognitive structures (e.g., Power \& Dalgleish, 2016) has driven advances in behavioural (Tyron, 2005) and cognitive therapy (Beck, 1979; Young, 1999; Young, Klosko, \& Weishaar, 2006). Moreover, the development of more nuanced understandings of the cognition-emotion interactions underpinning more specific clinical presentations has improved how we assess, formulate and provide therapy for people with a range of psychological difficulties such as anxiety, eating disorders, post-traumatic stress disorder and obsessive-compulsive experiences (e.g. Clark \& Wells, 1995; Ehlers \& Clark, 2000; Fox, Grange \& Power, 2015; Salkovskis, Forrester \& Richards, 1998; Wells, 1999). Thus, clear clinical advantage has been demonstrated in differentiating and delineating the sequelae of different emotions.

One such emotion which has begun to receive such delineation and differentiation is that of self-disgust, in which the basic emotion of disgust becomes directed at a core and stable feature of the self (Powell, Simpson \& Overton, 2015). As disgust is a visceral negative emotion driving behavioural responses of rejection and avoidance (Rozin, Haidt \& McCauley, 2000), it would be predicted that having such an emotion directed at the self may contribute to significant psychological difficulties. Indeed, several authors have begun to theorize on how such difficulties may develop. For example, Powell et al. (2015) postulate that self-disgust represents a distinct emotion schema (Izard, 2007, 2009). Specifically, an initial self-disgust reaction may be generated by cognitive appraisal processes, such as 
negatively evaluating one's features or actions, or by more associative processes, in which disgust initially generated by an external stimulus then becomes elicited by the part of the self associated with this stimulus. If this initial self-disgust reaction becomes elaborated on, for example, by rumination or disgust-centred feedback from others, then it may develop into an over-arching framework through which one views oneself, and may guide subsequent perception, attention, memory and cognitive processes in a manner consistent with the selfdisgust schema; thus, the schema becomes self-perpetuating. It is important, however, to note the caveat that emotions are likely to influence appraisal as much as the other way round and such uni-directional assumptions are likely to be simplistic. Powell et al. (2015) conclude that a self-disgust schema is likely developed in childhood in response to disgust-based criticism or abuse, with self-disgust in adulthood likely shaped by trauma or a change in the nature of how the self is experienced.

Regardless of aetiological considerations, in order for self-disgust to be considered theoretically valid, both the emotion schema of self-disgust and its sequelae should be distinguishable from other emotions, most notably from other negative self-referent emotions such as guilt, shame and self-hatred. Theoretically, emotions are considered to comprise a number of related subsystems, including a cognitive appraisal system, a subjective feeling state, a physiological response, and a set of action urges or desired behavioural responses (Lang, 1988; Rachman \& Hodgson, 1974). Thus, in order for self-disgust to be considered a theoretically distinct emotion, it should be distinguishable across these domains.

Moreover, it has been argued that the centrality of the core emotion of disgust does enable self-disgust to be differentiated from other negative self-referent emotions across appraisal content, subjective and physiological experiences, and associated behavioural repertoires (e.g., Powell et al. 2015). To illustrate, disgust or contamination-based appraisals are necessary to generate self-disgust, whereas guilt, shame and self-hatred can be generated 
in the absence of such appraisals - for example, the appraisal "I've been made a fool of" may generate shame but not self-disgust. Conversely, disgust-specific appraisals, such as "I look rotten" or "I make other people feel sick", can be considered to generate self-disgust but not necessarily guilt, shame or self-hatred (Powell et al., 2015).

Furthermore, self-disgust is subject to generation via more associative processes, in which one feels oneself to be dirtied due to past contact with a contaminated object (Rachman, 2004), as may occur, for example, in sexual trauma; however, guilt, shame and self-hatred would appear to be less subject to such associative processes. The emotion of disgust also distinguishes the subjective and physiological experiences of self-disgust, guilt, shame and self-hatred. Self-disgust, as with more general disgust reactions, is characterised by a strong physical sense of revulsion and nausea that is not associated with shame or selfhatred (Keltner, 1996; Powell et al., 2015; Robins \& Schriber, 2009; Scherer \& Wallbott, 1994). Associated behavioural repertoires are also distinct - although self-disgust is sometimes conflated with self-hatred as an extreme form of self-attacking (e.g. Gilbert, Durrant and McEwan, 2006), self-disgust is likely to influence self-to-other as well as self-toself relations, triggering behaviours such as social withdrawal which may not necessarily be present in self-hatred. Self-disgust is also likely to drive more contamination-driven behaviours not seen in the other self-referent emotions, such as extreme attempts to cleanse or remove the disgusting self. Finally, while Gilbert et al. (2004) highlight that the experience of self-disgust may at times include some kind of self-criticism, it can also be differentiated from self-criticism, which has none of the more visceral aspects of self-disgust (e.g., Simpson et al., 2010). These assertions have been borne out in qualitative research examining the micro-sequelae of self-disgust (e.g. Espeset et al., 2012; Powell et al., 2014).

The final existing construct with which self-disgust is often associated is "mental contamination", in which mental events generate an internal sense of dirtiness in the absence 
of a physical contaminant (Rachman, 2004). Although disgust would appear to be the central emotion here, mental contamination can be differentiated from self-disgust by the centrality of the self in both concepts. Self-disgust requires disgust-based appraisals to be directed at a core and stable feature of the self; however, mental contamination can be triggered by mental events which bear no relevance to the self (e.g. images of something dirty). Nonetheless, while mental contamination does not need involve self-disgust, and self-disgust does not need involve the broader characteristics of mental contamination, they can often co-occur (i.e. selfdisgust exists in certain forms of mental contamination). Although a small minority of studies assess more permanent feelings of contamination generated by the self or body (specifically after trauma; Jung \& Steil, 2012, 2013; Steil, Jung \& Stangier, 2011), the vast majority of studies of this construct more broadly define mental contamination as a sense of dirtiness created by any internal event (e.g. Coughtrey, Shafran, Lee \& Rachman, 2012; Rachman, 2004).

Thus, it appears that, at least theoretically, self-disgust represents a distinct cognitiveaffective schema. However, whether self-disgust represents a clinically useful concept remains to be demonstrated. A number of criteria would speak to the clinical utility of selfdisgust. In her review of the concept of apathy in people with Parkinson's disease, Bogart (2010) argued that in order to be clinically useful a concept must first have a shared definition of a real and meaningful experience that people encounter. Thus, theoretical definitions of self-disgust must map on to people's real-life accounts of the phenomenon. In addition to this, a concept must demonstrate adequate construct and face validity, in that its operationalization and measurement map on to this underlying meaningful conceptualization, and adequate predictive validity, in that measurement of this construct can provide useful information about a person's future and to which kind of intervention they may be most responsive. 
Qualitative descriptions of self-disgust and studies assessing the psychometric properties of self-disgust scales can inform the conceptual definition and construct validity criteria respectively. However, establishing the predictive validity of self-disgust is more difficult, and requires designs which can disentangle the precise relationship between selfdisgust and various mental health difficulties. There are four potential mechanisms through which self-disgust may relate to psychopathology, with each mechanism having differing implications for the predictive (and thus clinical) utility of self-disgust.

Firstly, as postulated by Powell et al. (2015), self-disgust may be a causal factor driving the development of a particular mental health presentation. This causal influence may occur through two pathways - self-disgust may represent a latent factor shaped by childhood experiences which when activated triggers a particular mental health presentation (for example, childhood sexual abuse may trigger the development of self-disgust which in turn predicts the development of borderline personality features in adulthood). Alternatively, selfdisgust may be triggered by a severe change in how the self is experienced in adulthood, which in turn drives a particular mental health presentation (for example, experiencing incontinence in adulthood may create self-disgust which in turn may predict feelings of depression and social withdrawal). Such a causal relationship would highlight the need for early intervention to target the cognitive, emotional and behavioural underpinnings of selfdisgust.

Secondly, self-disgust may be a consequence of a mental health difficulty (for example, if one becomes depressed, and evaluates one's subsequent behavioural inactivity as disgusting). Such a relationship would limit the predictive utility of self-disgust as a concept, although it may still retain some utility if it points to a potentially important target for later treatment once other issues are resolved. Thirdly, self-disgust may represent an unrelated correlate of a mental health difficulty - for example, involvement in armed conflict may 
cause the separate development of both self-disgust and post-traumatic stress disorder, with the two having little relation to each other. This would render self-disgust of little predictive utility in considering a specific mental health presentation, although if it contributes to general distress levels it may still be a useful focus for treatment. Finally, self-disgust may be a correlate of other constructs (such as shame) which do explain the development of a mental health difficulty. For example, sexual abuse may create both feelings of shame and selfdisgust, but only shame may contribute to the development of a dissociative disorder. Such a relationship would lend little clinical and predictive utility to the concept of self-disgust. However, while it is important to note the differences between the various self-referent constructs discussed and their relationships with each other, it is also important to note that bi-directional relationships and feedback loops are also likely to exist between self-disgust and these other constructs which are implicated in psychological wellbeing (see the schematic model of self-disgust by Powell et al., 2015a).

Various types of evidence could support or refute each of the four mechanisms outlined above. Particularly useful are prospective studies examining the relationship between self-disgust and mental health difficulties over time while controlling for related variables, and treatment outcome studies examining whether targeting and reducing self-disgust results in subsequent amelioration of symptoms of a mental health difficulty. Conceptual literature reviews (e.g. Black \& Lobo, 2008; Bright, Kayes, Worrall \& McPherson, 2015) which draw on such a diverse range of literature can offer a useful framework for addressing these issues.

This review therefore aims to evaluate the clinical utility of self-disgust according to these criteria. Specifically: 
- In order to evaluate the meaningfulness of the conceptual definition of selfdisgust, the review will examine qualitative research which has explored whether and how individuals experiencing mental distress experience disgust for the self.

- In order to evaluate the construct validity of the measurement of self-disgust, the review will examine how self-disgust is assessed in studies examining its relationship to mental health difficulties.

- In order to evaluate the predictive validity of self-disgust, the review will examine research linking self-disgust to mental health difficulties and evaluate this research according to the four competing models described above.

The review will subsequently draw conclusions about the clinical utility of self-disgust as a concept in understanding mental health difficulties.

\section{Method}

\subsection{Search Strategy}

The electronic databases PsycINFO, PubMed, CINAHL and Web of Science were searched to retrieve empirical studies published up to March 2017. Each database was searched separately using the following search string: "disgust" OR "self-disgust" OR "mental contamination" OR "mental pollution". Although it is argued that mental contamination can be distinguished from self-disgust, mental contamination is a label given to a phenomenon that can involve, and often does involve, self-directed disgust reactions, hence its inclusion here for comprehensiveness. All searches were also limited to papers published in peer-reviewed academic journals and in English. No date limiters were used. The citation and reference lists of all included papers were also checked for relevant papers. Papers were screened according to the eligibility criteria below. The search was primarily conducted by the first author with input from an academic librarian. Decisions around paper 
inclusion or exclusion were also made primarily by the first author with checking from the second and third authors. Figure 1 presents a flow diagram documenting this search strategy.

\subsubsection{Eligibility Criteria}

\section{Inclusion criteria}

Papers were considered eligible for inclusion in the review if they:

Specifically and predominantly examined feelings of disgust towards the self, as assessed via:

- The use of an established self-disgust scale

- $\quad$ The use of a visual analogue scale specifically measuring self-disgust

- $\quad$ The use of an established disgust measure as used in relation to some core feature of the self

- Qualitative exploration specifically of feelings of disgust towards the self

- The use of a scale which measured feelings of dirtiness or contamination specifically elicited by a core feature of the self (as opposed to elicited by transient mental events unrelated to the self). The only scales which met this criterion were the Feeling of Being Contaminated Scale (Jung \& Steil, 2011), which evaluates feelings of disgust and contamination elicited by one's own body following sexual assault, and the Sexual Assault Related Appraisals: Mental Contamination Scale (SARA; Fairbrother \& Rachman, 2004), which assesses feelings of contamination elicited by whole-self evaluations following sexual assault (e.g. "I feel contaminated by my sexual assault/rape, no matter how much I wash") 
Were published in a peer-reviewed academic journal.

Were available in the English language.

Included a validated measure of mental distress or have sampled a population who have already been assessed as presenting with considerable psychological distress (for example, individuals with a diagnosis of post-traumatic stress disorder).

\section{Exclusion criteria}

Studies were excluded from the review if they:

Measured disgust in a manner which did not relate to a core feature of the self

Did not predominantly measure self-disgust but rather a related construct, such as guilt, shame or self-loathing.

Operationalised mental contamination predominantly in a way which did not relate to a core feature of the self (e.g. as intrusive mental images) - for example, via the Vancouver Obsessive Compulsive Inventory - Mental Contamination Scale (Radomsky, Rachman, Coughtrey and Shafran, 2014) or the Mental Pollution Questionnaire (Fairbrother \& Rachman, 2004).

Measured the experimental manipulation of a construct (e.g. inducing mental contamination).

Were theoretical rather than empirical.

Examined the relationship between self-disgust and a construct which has yet to demonstrate a robust connection with mental distress (e.g. flow, sense of superiority; Hirao \& Kobayashi, 2013; Satoh, 2001; Kodaira, 2002). 


\section{[INSERT FIGURE 1 HERE]}

\subsection{Risk of bias assessment}

Risk of bias in the included studies was assessed using a tool adapted for assessing bias in observational research from the Agency for Healthcare Research and Quality (Taylor, Hutton \& Wood, 2015; Williams, Plassman, Burke \& Benjamin, 2010). This tool specifies nine areas of relevance to the research question posed in this review, enabling methodologically diverse research papers to be compared within a coherent framework. To illustrate, no matter the methodology employed, it was important to determine whether or not self-disgust had been assessed in a valid way, whether the analyses conducted were appropriate, and whether potential confounds influencing the predictive validity of selfdisgust were controlled. This tool has been used in previous reviews which included methodologically heterogeneous studies (Cherry, Taylor, Brown, Rigby \& Sellwood, 2017). Risk of bias was evaluated in relation to the specific research questions posed in the review, as opposed to an attempt to make general claims about bias in the studies included.

\subsection{Data synthesis}

Data relevant to the study's aims were extracted from all studies and collated into a table. Themes and data from qualitative self-disgust papers were examined and areas of convergence and divergence extracted. Effect sizes from quantitative papers were extracted and converted to a common metric (Pearson's $r$ ) to enable comparison, and findings were narratively synthesised. Methodological heterogeneity precluded meta-analytic integration of the findings. 


\section{Results}

\subsection{Result of assessment of risk of bias}

The results of the risk of bias assessment are presented in Table 1. The most pertinent methodological biases pertained to the selection of participants, the assessment of selfdisgust, and control for confounding variables. Specifically, studies tended to over-rely on samples of undergraduate students who completed various measures of psychological distress; it is difficult to generalise conclusions based on research in a relatively highfunctioning sample to more acutely distressed samples. Conversely, when studies recruited clinical samples, they tended to recruit participants based on membership of broad diagnostic categories with questionable validity (e.g., borderline personality disorder). This makes the specificity of the relationship between self-disgust and psychopathology difficult to disentangle. Furthermore, there was considerable variability in how self-disgust was assessed across studies, ranging from validated broad measures of self-disgust to visual analogue scales. Different measures likely captured different aspects of self-disgust. Control for confounding variables was typically partial and involved other measures of disgust (e.g. disgust propensity) or more general measures of well-being (e.g. anxiety). Studies rarely controlled for the confounding impact of other negative self-referent emotions such as shame. The implications of these biases are discussed throughout the results section.

\section{[INSERT TABLE 1 HERE]}

\subsection{Study characteristics}

Thirty-one papers (twenty-seven quantitative, three qualitative, one mixed) were included in the review. The context of the mental health difficulties in which self-disgust was studied tended to be highly variable. Specific difficulties examined included trauma-related 
difficulties, depression and anxiety, eating disorders or body-image related difficulties, selfharm, borderline personality disorder, and obsessive-compulsive difficulties. One paper (Overton et al., 2008) additionally assessed the psychometric properties of a self-disgust scale. As the relationship between self-disgust and psychopathology may vary according to the particular clinical presentation, these difficulties were considered separately below.

Table 2 provides a detailed breakdown of the characteristics of included studies.

Table 2 around here please

\subsection{Conceptualisation of self-disgust}

Qualitative examinations of people's experiences of self-disgust can inform whether the theoretical construction of self-disgust maps on to people's real-life experiences, and thus whether the concept captures a meaningful real-world phenomenon. Such research can delimit the boundaries of the concept, and indicate the aspects of experience that are captured within it. Thus, it can contribute to the definition of a meaningful concept and suggest how best quantitative measures can capture its breadth and depth. Qualitative studies have explored self-disgust in the context of depression (Powell et al., 2014), eating disorders (Espeset et al., 2012), physical health problems (Jones et al., 2008), and sexual trauma (Jung \& Steil, 2012).

Similar themes have emerged across these papers, although there are also areas of divergence. In perhaps the most comprehensive qualitative exploration of self-disgust, Powell et al. (2014) highlighted the importance of the visceral nature of self-disgust, underscored by diffuse feelings of nausea which are triggered by a range of self-related cues. Participants also reported experiencing a pervasive and constant background sense of self-disgust which became more intense when presented with specific triggers (e.g. having to focus on an aspect of the self), as well as severe psychological and behavioural reactions to self-disgust. This 
included a desire to literally cut away or cleanse the disgusting part of the self, dissociating the "disgusting" self from the rest of one's identity, and withdrawing from other people due to a belief that the self was toxic. A phenomenologically similar experience was described in the other studies (Espeset et al., 2012; Jones et al., 2008; Jung \& Steil, 2012), with particular commonalities including a physical sense of revulsion and nausea, social withdrawal, extreme attempts at cleansing (Jung \& Steil, 2012) and a degree of dissociation and cognitive avoidance from the "disgusting" part of the self (Espeset et al., 2012). However, whereas in the Powell et al. (2014) study feelings of self-disgust were elicited by whole-self evaluations which were driven by diffuse causal pathways, elicitors of self-disgust in the other studies were more specific, i.e., a diseased (Jones et al., 2008) or trauma-affected (Jung \& Steil, 2012) body part or the body itself (Espeset et al., 2012), and typically had a clearer causal pathway. Nonetheless, the overall phenomenological experience appeared very similar.

Thus, self-disgust appears to represent a real and meaningful experience for people with significant psychological and behavioural consequences, which encompasses both an enduring and stable cognitive-affective component and a more intense and transient selfdisgust emotional reaction. It was elicited by whole-self diffuse evaluations, or by more specific evaluations, such as evaluations of behaviour. Therefore, a clear and meaningful definition of self-disgust can be derived and mapped on to personal accounts of the experience; such a clear construct definition is an essential first step in establishing construct validity (Schwab, 1980). This definition posits self-disgust as a psychologically destructive emotion, sometimes latent but easily triggered, with visceral content and resulting in a desire/need both to avoid the disgusting aspect of the self psychologically and behaviourally and to attempt to expunge it from the self. 


\subsection{Measurement of self-disgust}

Examination of the measurement of self-disgust can inform how well a quantitative assessment of self-disgust maps on to this conceptual definition. Considerable heterogeneity exists in how self-disgust has been operationalised within the literature. Psychometric measures designed specifically to assess self-disgust (e.g. Overton et al., 2008; Schienle, Ille, Sommer \& Arendasy, 2014) have only recently been developed. In the absence of standardized self-disgust scales, the most frequently employed measures of self-disgust have simply involved utilizing visual analogue scales asking individuals to rate the intensity with which they experience self-disgust (e.g. Abdul-Hamid et al., 2014; Badour et al., 2012; Badour et al., 2014; Dyer et al., 2015). Such single-item measures are unlikely to capture the full complexity of a self-disgust cognitive-affective schema, and may instead capture a more transient but intense self-disgust emotional reaction. Perhaps resultantly, such measures have not been subject to any rigorous psychometric tests of reliability over time, and validity has only been established relative to more general measures of disgust rather than relative to other negative self-referential emotions. Additional brief measures of feelings of disgust towards the self have also been developed specifically in relation to sexual trauma, including the Feeling of Being Contaminated Scale (Jung \& Steil, 2012,2013; Steil et al., 2011) and three items from the Sexual Assault and Rape Appraisals (SARA; Fairbrother \& Rachman, 2004). Again however, such scales appear to focus on a specific aspect of self-disgust (disgust towards trauma-affected body parts, generated by more associative processes following links with a real contaminant), and have yet to be subject to rigorous psychometric testing.

Two multi-item measures of self-disgust have been developed and validated in the literature. The Self-Disgust Scale (Overton et al., 2008), developed and validated in a UK convenience sample (largely comprising female undergraduate students), comprises two 
factors, a "disgusting self" scale, in which disgust becomes targeted at stable, context independent aspects of one's appearance or personality, and a "disgusting ways" scale, in which disgust is directed at one's behaviour. The SDS has evidenced strong internal consistency (Cronbach's alpha $=.91)$, suggesting that it measures a coherent underlying construct, and strong test-retest reliability, suggesting the scale is measuring a construct which is relatively stable over time. Moderate correlations with more general measures of disgust $(r=.25)$ suggests that the scale is measuring a construct which centres on the core emotion of disgust. However, correlations between the SDS and measures of other negative self-relevant emotions were not described, thus limiting conclusions around the convergent and discriminant validity of the SDS. Moreover, closer scrutiny of the SDS reveals a lack of definitional clarity and this has been recognised by the authors involved in this work. For example, the SDS includes the phrase "I hate being me", which while potentially copresenting, does not appear to tap into the argument often made regarding the need to differentiate self-disgust from other related concepts such as self-hatred. Given that the development of the first version of the SDS pre-dates the qualitative research on the phenomenology of the concept, it is argued this reduces the scale's face validity. However, the issue has been partly addressed (Powell et al., 2015b), who modified the SDS in an attempt to improve this based on qualitative work (Powell et al., 2014).

The Questionnaire for the Assessment of Self-Disgust (Schienle, Ille, Sommer \& Arendasy, 2014) appears to have a similar factor structure to the SDS, producing "personal “ and "behavioural" disgust subscales. Unfortunately, the study validating the QASD is not available in the English language. However, subsequent studies (e.g. Schienle et al., 2015) using the QASD report strong internal consistency $(\alpha=0.85)$ and test-retest reliability. 
Differing measures of self-disgust are likely to capture different elements of this construct, with visual analogue scales perhaps measuring a transient emotional reaction and multi-item scales like the SDS and QASD better capturing the underlying construct suggested by qualitative research, including its cognitive and behavioural elements. Thus, in considering the relationship between self-disgust and mental distress, it is crucial to consider which element of self-disgust is likely being assessed by a particular measure. Although the SDS and QASD are more likely to fully capture the construct of self-disgust, their development and validation within predominantly student, largely female, non-clinical samples, may render them less sensitive to detecting different manifestations of self-disgust in other populations. To illustrate, the specific body-part elicitors of self-disgust evidenced in the Jones et al. (2008) and Jung and Steil (2011) studies may be less likely to be detected by the more whole-body evaluation items on the SDS and QASD. Thus, the likely sensitivity and specificity of the measure in detecting self-disgust in a particular population should also be considered when evaluating the relationship between self-disgust and mental distress. Therefore, although measures exist which appear to adequately capture the construct of selfdisgust as evidenced in the qualitative literature, these assessments may be less sensitive to capturing manifestations of self-disgust in specific populations. Furthermore, much of the self-disgust literature has employed a measure of self-disgust which have yet to establish adequate construct validity and are likely to only partially capture the concept of self-disgust. These issues will be given careful consideration in considering the literature examining the relationship between self-disgust and mental distress.

\subsection{The relationship between self-disgust and mental distress}

This literature pertains to the predictive validity of self-disgust in determining clinical outcomes. Throughout this section of the review, the relationship between self-disgust and 
mental health difficulties will be considered according to how well it fits with the four potential mechanisms outlined in the introduction, each of which has different implications for the predictive, and thus clinical, utility of self-disgust.

\subsubsection{Self-disgust and mood difficulties}

Six papers examined the relationship between self-disgust and depression or anxiety (see appendices A and B). These studies employed broad multi-item measures of self-disgust, indicating that they were likely capturing the full cognitive-affective schema. Effect sizes tended to be moderate to large when examining the relationship between self-disgust and depression, although beta values were weaker after other negative self-referential emotions were controlled. Where anxiety was measured, effect sizes tended to be small to moderate, and beta values were further reduced when other variables were controlled. Behavioural selfdisgust appeared to have a stronger predictive effect on anxiety than physical self-disgust. Many of these studies positioned self-disgust as a mediating variable which attempted to explain the relationship between various life events (e.g. illness) or dispositions (e.g. dysfunctional attitudes or biases) and the subsequent development of depression or anxiety. Five of these studies employed a cross-sectional survey design in order to test these hypotheses, with one employing a longitudinal design.

To illustrate, two cross-sectional studies conducted in community samples (Overton et al., 2008; Simpson et al., 2010) demonstrated that the relationship between dysfunctional attitudes (for example, perfectionistic tendencies) and depression was partially mediated by the effect of depression on self-disgust, with the mediating effect of self-disgust remaining significant independent of the mediating effect of low self-esteem (Simpson et al., 2010). A longitudinal study (Powell et al., 2013) leant further support to the conceptualisation of selfdisgust as a concept which mediates the relationship between dysfunctional attitudes and 
depression. Specifically, over a 12-month period in a non-clinical sample, self-disgust levels at baseline significantly predicted depressive symptoms six months $(\beta=0.30)$ and 12 months ( $\beta=0.26)$ later when controlling for baseline depressive symptoms. However, when controlling for baseline levels of self-disgust, baseline depressive symptoms did not significantly predict levels of self-disgust at six months $(\beta=0.10)$ or 12 months $(\beta=0.03)$. Furthermore, the impact of baseline levels of dysfunctional attitudes on depressive symptoms was mediated by self-disgust at 6 months, $\beta=0.13$, suggesting that at least some of the impact of cognitive biases on depressive symptoms is mediated by its impact on self-disgust. However, there was also a significant impact of 6-month self-disgust on 12-month dysfunctional attitudes, suggesting that perhaps a bi-directional relationship in which selfdisgust, once established, functioned to perpetuate cognitive biases. Two studies (Azlan et al., 2017; Powell et al., 2016), which examined the predictive role of self-disgust on the development of depression in the context of a (disgust-related) physical health stressor, leant further tentative support to the conceptualization of self-disgust as a contributor to the aetiology of mood difficulties. Powell et al. (2016), in their cross-sectional examination of the role of self-disgust in the development of depression in cancer patients, found that selfdisgust mediated the relationship between disgust-related cancer side effects and depressive symptomatology in patients high in disgust-sensitivity but not in patients low in disgust sensitivity, with both physical and behavioural self-disgust exhibiting significant direct effects on depression. Similarly, Azlan et al. (2017) reported that physical self-disgust was strongly predictive of depression in cancer patients. However, another cross-sectional study (Laffan et al., 2015) found no relationship between levels of self-disgust and depression in a sample of older adult living in residential care, although it should be noted that overall levels of self-disgust were very low within this sample. 
Overall the evidence converges to support the conceptualisation of self-disgust as a latent factor with a significant aetiological role in the development of depression, thus lending most support to the first of our potential relationship models. The evidence further appears to suggest that once the link between self-disgust and depression is established, self-disgust then subsequently influences other depression-maintaining processes, such as cognitive biases. This would give the concept of self-disgust significant predictive and clinical utility in understanding depression. However, the relevance of self-disgust to anxiety appears to be much weaker. Moreover, conclusions are bounded by a number of caveats, most notably an over-reliance on community samples in which overall levels of distress are relatively low and a failure to control for potential confounding variables such as shame or self-hatred. It is therefore difficult to rule out mechanism 4, in which self-disgust only relates to psychopathology through its relationship to other negative self-referent emotions.

\subsubsection{Self-disgust and trauma-related difficulties}

Ten studies have examined the relationship between self-disgust and the development of trauma-related difficulties (see appendix C). Effect sizes have been quite variable (ranging from non-existent to large) depending on how self-disgust and trauma-related difficulties were operationalised. In particular, studies which examined the role of peritraumatic selfdisgust (Badour et al., 2012, 2013, 2014) have evidenced much weaker effect sizes than studies which have measured a more enduring self-disgust reaction (e.g. Brake et al., 2017; Dyer et al., 2015, Ille et al., 2014 Rusch et al., 2011). All of these studies employed crosssectional, case-control, or retrospective designs, and therefore were limited in their ability to inform the predictive validity of self-disgust. However, a number of treatment outcome studies (Jung \& Steil, 2012, 2013; Jung, Steil \& Stangier, 2013) evaluating the efficacy of 
self-disgust based interventions on post-traumatic symptoms enable us to evaluate this further.

To illustrate, peri-traumatic self-disgust has been demonstrated to have no effect on post-traumatic stress symptoms once other variables are controlled (Badour et al., 2012), although it has been demonstrated to significantly predict mental contamination following trauma (Badour et al., 2014), which in turn significantly predicted post-traumatic stress symptom severity (Badour et al., 2013). However, significantly higher rates of body-focused self-disgust have been observed in victims of childhood sexual abuse who have a diagnosis of PTSD symptoms compared to a healthy control group (Dyer et al., 2015); moreover, women with a diagnosis of PTSD who had experienced childhood sexual abuse were significantly more likely to associate themselves with disgust than with anxiety in an implicit association test (Rusch et al., 2011). Moreover, self-disgust has been demonstrated to mediate the relationship between post-traumatic stress severity and suicide risk (Brake et al., 2017).

A coherent framework is needed in order to integrate these divergent findings. It is possible, for example, that a peri-traumatic self-disgust response only results in development of post-traumatic symptoms when it is elaborated in to an over-arching self-disgust framework. Further, peri-traumatic self-disgust may promote vulnerabilities such as mental contamination which enable this elaboration. However, the retrospective and cross-sectional nature of these studies prohibits clear conclusions and thus restrict our ability to evaluate the predictive validity of self-disgust.

Nonetheless, a small number of treatment outcome studies enable further evaluation of this relationship. A case study (Bowyer et al., 2014) describing the integration of compassion-focused techniques to target self-disgust within an overall trauma-focused CBT intervention evidenced considerable reductions in post-traumatic stress symptoms. Similarly, 
a 2-session intervention specifically targeting contamination-based appraisals and imagery evidenced significant reductions in PTSD symptoms in a case study (Jung \& Steil, 2012), a small scale intervention study (Jung, Steil \& Stangier, 2011) and a randomized controlled trial (Jung \& Steil, 2013). Demonstrating that reductions in self-disgust results in subsequent reductions in post-traumatic symptoms indicates that self-disgust at least plays a significant role in the maintenance, if not the development, of these symptoms.

Thus, overall empirical research on self-disgust and trauma is suggestive of a causal role for self-disgust, thus lending support to the first of our proposed relationship models. However, results are confounded by the considerable heterogeneity in the operationalisation of self-disgust, and as with the depression literature, by a reliance on retrospective crosssectional studies and a failure to control for other negative self-referential processes. Thus, it is also difficult to rule out the fourth potential relationship mechanism, in which self-disgust only relates to post-traumatic difficulties due to its relationship with other variables such as shame.

\subsubsection{Self-disgust and difficulties with body-image}

Five quantitative studies examined the relationship between self-disgust and problems associated with disordered eating or body image (see appendix D). Effect sizes were moderate to large when the zero-order correlations were considered, although beta values were much smaller when other negative self-referential emotions such as shame were controlled. All studies employed a cross-sectional or case-control design, and measurement of self-disgust varied across studies. An additional qualitative study (Espeset et al., 2012) linked self-disgust to specific eating disordered behaviours, in particular social withdrawal, food restriction, and dissociation from the body. 
To illustrate, individuals with body-image related difficulties (eating disorders, body dysmorphic disorder) self-report significantly higher levels of disgust relative to controls both when focusing on their own bodies (Bornholt et al., 2005; Neziroglu et al., 2010) and in multi-item measures of self-disgust (Ille et al., 2014). In addition to significantly predicting overall eating difficulties, self-disgust also significantly moderated the relationship between eating disorder symptoms and suicidal ideation, such that eating disorder symptoms predicted suicidal ideation in those high in self-disgust but not in those low in self-disgust (Chu et al., 2015). This finding may suggest that self-disgust underpins a more severe and enduring manifestation of eating difficulties, which may in turn predict suicidal ideation. Moreover, self-disgust uniquely predicted bulimia independently of the effects of shame (Olatunji et al., 2015), and significantly mediated the relationship between shame and bulimia. However, the relationship between self-disgust and bulimia became weaker (although still significant) when shared variance was attributed to shame, suggesting that failure to consider the broader emotion of shame may result in over-estimation of the specific effects of self-disgust.

Although the above findings suggest a role for self-disgust in body-image difficulties, albeit a more modest one when shame is also considered, they are bounded by their crosssectional nature, as well as their use of a convenience rather than a clinical sample. These methodological difficulties limit the specificity of conclusions regarding precisely how selfdisgust relates to eating pathology across the spectrum of eating disorder severity. Although the qualitative paper (Espeset et al., 2012) suggested that self-disgust precipitates and drives eating disordered behaviours such as food restriction and avoidance of body awareness, these causal inferences are similarly limited and require empirical testing.

Thus, the research on self-disgust in the context of body-image difficulties is inconclusive with regard to which of the four potential relationship models it best fits. However, given suggestions in the qualitative literature that self-disgust drives eating 
disordered behaviour (rather than vice versa), the significant (albeit much weaker) contribution of self-disgust to these difficulties independent of the effects of shame, and the moderating impact of self-disgust on suicidal ideation in the context of these difficulties, some very tentative support is lent to the first predictive model, which posits that self-disgust is causally related to the development of body-image difficulties.

\subsubsection{Self-disgust and self-harm}

Three papers explicitly examined the relationship between self-disgust and self-harm (see appendix E). Effect sizes were reported for only one of these studies (Bachtelle \& Pepper, 2015) and are in the moderate to large range. Self-disgust was operationalised differently across studies, with two studies (Bachtelle \& Pepper, 2015; Smith et al., 2015) employing a broad multi-item measure of self-disgust, and one (Abdul-Hamid et al., 2014) employing a visual analogue measure. Two employed cross-sectional designs (Bachtelle \& Pepper, 2015; Smith et al., 2015) and one (Abdul-Hamid et al., 2014) employed an experimental design, with studies indicating a bi-directional relationship between self-disgust and self-harm.

To illustrate, Bachtelle and Pepper (2015) reported strong positive correlations between self-disgust and shame linked to self-injury related scars, and moderate negative correlations between self-disgust and the ability to experience personal transformation or growth following self-injury, suggesting that self-disgust may inhibit recovery from selfharm. Similarly, self-disgust significantly mediated both the relationship between depression and non-suicidal self-injury and the relationship between childhood sexual abuse and lifetime self-injury status (Smith et al., 2015), suggesting both that adverse life events exert their influence on self-injury partially through their effects on self-disgust and that self-disgust in turn increases the risk of depression following self-injury. Abdul-Hamid et al.'s (2014) 
experimental study lends further support to the complexity of this relationship. Specifically, when participants reflected on negative aspects of the personality and then their body (by writing a 3-minute free-narrative on this) and rated both changes in their disgust levels and changes in their self-harm urges subsequently, more frequent references to disgust terms in participant narratives was significantly related to an increase in urge to self-harm.

Overall, these findings tentatively suggest a reciprocal relationship between selfdisgust and self-harm urges, with self-disgust both predicting subsequent self-harm and generated as a response to self-harm. Thus, these findings are supportive of both model 1, in which self-disgust has a causal influence on engagement in self-harm, and model 2, in which engagement in self-harm predicts subsequent self-disgust.

\subsubsection{Self-disgust and obsessive-compulsive symptoms}

Three papers (see appendix F) examined the relationship between self-disgust and obsessive compulsive difficulties, two of which have already been discussed in relation to post-traumatic difficulties (Badour et al., 2012) and eating disorders (Olatunji et al., 2015). Effect sizes were moderate, although beta values reduced when other variables are controlled. One of these studies (Badour et al., 2012) assessed peri-traumatic self-disgust and its subsequent impact on the development of obsessive-compulsive difficulties. The other studies assessed self-disgust using the multi-item Self-Disgust Scale. Two of these studies were cross-sectional (Badour et al., 2012; Olatunji et al., 2015) and one employed an experimental design. Results tentatively indicated that self-disgust directed obsessive-compulsive behaviours, rather than vice versa, and that self-disgust made a unique contribution to this process independent of other negative self-referential emotions.

To illustrate, peri-traumatic self-disgust made a unique but small contribution to obsessive-compulsive difficulties independent of the effects of depression, disgust-sensitivity 
and post-traumatic cognitions (Badour et al., 2012), and general self-disgust made a small but significant independent contribution to obsessive-compulsive symptoms independent of the effects of shame (Olatunji et al., 2015). Experimentally-manipulated excessive engagement in health-related behaviours had no impact on self-disgust (Olatunji et al., 2014), suggesting that these behaviours were a consequence rather than a cause of self-disgust.

Thus, the evidence on self-disgust and obsessive-compulsive difficulties is very weakly suggestive of the first causal model. However, such conclusions are very tentative. Olatunji et al. (2014) employed a community sample who were not experiencing obsessive compulsive symptoms and manipulated only a small range of behaviours which may be encompassed within obsessive-compulsive difficulties. It is therefore possible that when such behaviours occur in the context of significant psychological distress, they do drive further self-disgust. It is also probable that particular obsessive-compulsive symptoms not captured in that study (such as intrusive thoughts) drive further self-disgust. Thus, we cannot rule out model two, in which self-disgust is a consequence of obsessive-compulsive difficulties, or a reciprocal relationship between models one and two.

\subsubsection{Self-disgust and a diagnosis of borderline personality disorder}

Four studies (see appendix $G$ ) have reported on the relationship between self-disgust and a diagnosis of borderline personality disorder. Effect sizes, where reported, are in the large range. All four studies (Dudas et al., 2017; Ille et al., 2014; Schienle et al., 2013; Schienle et al., 2015) employed a case-controlled design and utilised multi-item measures of self-disgust (the QASD). Three of these studies (Dudas et al., 2017; Schienle et al., 2013; Schienle et al., 2015) also demonstrated differential patterns of activation in the amygdala brain regions in the client group relative to a control group, and an increased sensitivity to facial expressions of disgust in others. Schienle et al. (2015) postulated that the latter findings 
may have been due to life experiences which have shaped predictions of rejection, thus sensitising participants to expressions of disgust from others.

Although these studies are indicative of elevated levels of self-disgust in this group of individuals, a number of methodological limitations preclude us from drawing conclusions about the predictive relationship between self-disgust and such difficulties. The study designs do not enable conclusions around the direction of effects. Furthermore, the construct validity of borderline personality disorder is questionable, and is likely to encompass a highly heterogeneous group of people. Thus, findings that self-disgust is elevated in a very heterogeneous group of people does not enable conclusions about why this might be the case (i.e. the particular psychological processes that self-disgust might relate to in this group). Notwithstanding the heterogeneity within the category itself, participants in the above studies typically presented with numerous additional psychological difficulties. Thus, it is entirely possible that higher levels of self-disgust confer a more general risk for more severe manifestations of psychological distress, rather than the more specific difficulties associated with borderline personality disorder.

\section{Discussion and conclusions}

Overall, the review supports the construct validity of the concept of self-disgust qualitative explorations of the phenomenology of self-disgust appear to describe a meaningful and coherent experience, which is distinct from other negative self-referent emotions, and which is associated with significant negative outcomes. Quantitative measures of self-disgust would appear to map well on to these qualitative descriptions, although they may be less sensitive in populations for whom the elicitors of self-disgust are specific rather than diffuse. Psychometric testing of these measures further indicates a coherent underlying structure, which is stable over time, and which correlates appropriately (not so strongly that it is 
measuring the same construct, but not so weakly that it is completely unrelated to constructs it should theoretically relate to) with both other measures of disgust and measures of other negative self-referent emotions.

It is more difficult to determine the predictive validity of self-disgust, particularly over and above the predictive value of established constructs such as shame. The evidence does however tentatively suggest that self-disgust is implicated in the aetiology of a range of mental health difficulties, particularly in the areas of depression, trauma and eating disorders, with perhaps a more reciprocal relationship evident between self-disgust and self-harm. However, a number of caveats limit the strength of these conclusions. Firstly, a dearth of prospective studies means that conclusions about the direction of effects are based on a small number of papers, or based on inferences from studies in which self-disgust is most likely to have pre-dated the difficulty being examined (e.g. a physical health condition resulting in a change in the self, a trauma). Secondly, many studies did not control for the potentially confounding effects of other self-relevant emotions, in particular shame, and those that did reported a more modest (although still significant) unique contribution of self-disgust. Thirdly, many of the measures used to assess self-disgust, particularly in the area of trauma, may only capture a small part of the construct and may result in an over or under estimation of the strength of the relationship between self-disgust and mental health, particularly posttraumatic, difficulties. Fourthly, there is also an over-reliance on convenience rather than clinical samples, particularly in the research on depression and obsessive-compulsive difficulties; it is possible that the relationship between self-disgust and these difficulties is different when more severe manifestations of these difficulties are more prevalent in the sample. Finally, there is an over-reliance on between-group comparisons based on diagnostic categories which are considerably heterogeneous, or on examining the relationship between self-disgust and symptoms of a particular diagnostic category; this makes it difficult to infer 
the specific process through which self-disgust contributes to a particular mental health difficulty, and difficult to disentangle a causal influence of self-disgust from self-disgust simply being part of the phenomenology of the mental health difficulty. Research examining the relationship between self-disgust and specific symptoms, or more tightly related clusters of symptoms, may address this difficulty. To illustrate, it would be much more useful to know whether self-disgust predicts greater difficulty relating to other people than to know that selfdisgust is higher in people with a diagnosis of borderline personality disorder. Research focused on identifying the unique processes which mediate the relationship between selfdisgust and particular mental health difficulties would also add to this understanding.

Given the limitations outlined above, the clinical implications of this review should be interpreted with caution. However, the findings do suggest that self-disgust is a meaningful and distinct phenomenon with severe behavioural and psychological consequences, which is implicated in the development and maintenance of a range of mental health conditions. Thus, it should be taken into consideration in therapeutic practice. For example, the possibility that self-disgust influences an individual's presentation could inform the generation of additional early hypotheses which could subsequently further inform important areas for assessment, particularly in the conditions discussed above. Assessing for the physiological, behavioural, cognitive and subjective emotion states identified as key to self-disgust can subsequently inform formulation and targets for treatment. Given the sensitive nature of this topic, assessing self-disgust will need to be approached carefully, and qualitative research could usefully inform how clients would prefer this topic to be broached. Nonetheless, research on assessment of other sensitive topics, such as abuse or shame (e.g. Gilbert \& Proctor, 2006; Larkin \& Morrison, 2006) can inform this process. Moreover, the review has highlighted the potential benefits of specific therapeutic programmes which target (e.g. Jung \& Steil, 2012) self-disgust, albeit a more focused and contained aspect of self-disgust. New treatment 
programmes could build on this work by developing and adapting techniques which focus on the more diffuse aspects of self-disgust. Attempts to improve self-disgust therapeutically may derive insight(s) from techniques that have been used to alter state levels of self-focused disgust. For example, Powell et al. (2015c) showed the potential benefit of using selfaffirmation techniques for this purpose.

The review is not without limitations, e.g., the focus on published research only, lack of quantitative data synthesis (for example, meta-analysis), potential use of, largely, one reviewer only etc. However, the review can indicate several avenues for future research in order to further inform the clinical utility of self-disgust. As noted above, qualitative research exploring how clients experience assessment and intervention with self-disgust in therapy can inform how the concept can be most helpfully integrated into practice, as can treatment outcome studies which examine the efficacy of therapeutic strategies aimed at ameliorating self-disgust. Furthermore, there is a need for more prospective studies which examine the relationship between self-disgust and various mental health conditions over time, studies which examine the unique contribution of self-disgust to these difficulties as distinct from the contributions of shame and guilt, and studies which examine the processes through which self-disgust exerts its effects on mental health difficulties.

\section{References}

Abdul-Hamid, S., Denman, C., \& Dudas, R. B. (2014). Self-relevant disgust and self-harm urges in patients with borderline personality disorder and depression: a pilot study with a newly designed psychological challenge. PLoS One, 9(6), e99696. doi:10.1371/journal.pone.0099696

Azlan, H. A., Overton, P., Simpson, J., \& Powell, P. (2017). Differential disgust responding in people with cancer and implications for psychological wellbeing. Psychology and 
Health, 32(1), 19-37. DOI: 10.1080/08870446.2016.1235165

Bachtelle, S. E., \& Pepper, C. M. (2015). The physical results of nonsuicidal self-injury: The meaning behind the scars. Journal of Nervous and Mental Disease, 203(12), 927-933. doi:10.1097/NMD.0000000000000398

Badour, C. L., Bown, S., Adams, T. G., Bunaciu, L., \& Feldner, M. T. (2012). Specificity of fear and disgust experienced during traumatic interpersonal victimization in predicting posttraumatic stress and contamination-based obsessive-compulsive symptoms. Journal of Anxiety Disorders, 26(5), 590-598. doi:10.1016/j.janxdis.2012.03.001

Badour, C. L., Feldner, M. T., Blumenthal, H., \& Bujarski, S. J. (2013). Examination of Increased Mental Contamination as a Potential Mechanism in the Association Between Disgust Sensitivity and Sexual Assault-Related Posttraumatic Stress. Cognitive Therapy and Research, 37(4), 697-703. doi:10.1007/s10608-013-9529-0

Badour, C. L., Ojserkis, R., McKay, D., \& Feldner, M. T. (2014). Disgust as a unique affective predictor of mental contamination following sexual trauma. Journal of Anxiety Disorders, 28(7), 704-711. doi:10.1016/j.janxdis.2014.07.007

Baron, R. M., \& Kenny, D. A. (1986). The moderator-mediator variable distinction in social psychological research: Conceptual, strategic, and statistical considerations. Journal of personality and social psychology, 51(6), 1173.

Beck, A. T., \& Steer, R. A. (1991). BSS: Beck Scale for Suicide Ideation. Psychological Corporation.

Beck, A. T., Steer, R. A., \& Brown, G. K. (1996). Beck depression inventory-II. San Antonio, 78(2), 490-8. 
Bender, T. W., Gordon, K. H., Bresin, K., \& Joiner, T. E., Jr. (2011). Impulsivity and suicidality: The mediating role of painful and provocative experiences. Journal of Affective Disorders, 129(1-3), 301-307. doi:10.1016/j.jad.2010.07.023

Black, K., \& Lobo, M. (2008). A conceptual review of family resilience factors. Journal of Family Nursing, 14(1), 33-55. doi:10.1177/1074840707312237.

Blake, D. D., Weathers, F. W., Nagy, L. M., Kaloupek, D. G., Gusman, F. D., Charney, D. S., \& Keane, T. M. (1995). The development of a Clinician-Administered PTSD Scale. Journal of Traumatic Stress, 8(1), 75-90. doi:10.1002/jts.2490080106

Bogart, K. R. (2011). Is apathy a valid and meaningful symptom or syndrome in Parkinson's disease? A critical review. Health Psychology, 30(4), 386-400. doi:10.1037/a0022851

Bohus, M., Kleindienst, N., Limberger, M. F., Stieglitz, R.-D., Domsalla, M., Chapman, A. L., . . Wolf, M. (2009). The short version of the Borderline Symptom List (BSL-23): Development and initial data on psychometric properties. Psychopathology, 42(1), 32-39. doi:10.1159/000173701

Bornholt, L., Brake, N., Thomas, S., Russell, L., Madden, S., Anderson, G., . . . Clarke, S. (2005). Understanding affective and cognitive self-evaluations about the body for adolescent girls. British Journal of Health Psychology, 10(Pt 4), 485-503. doi:10.1348/135910705x41329

Bowyer, L., Wallis, J., \& Lee, D. (2014). Developing a compassionate mind to enhance trauma-focused CBT with an adolescent female: A case study. Behavioural and Cognitive Psychotherapy, 42(2), 248-254. doi:10.1017/S1352465813000362

Bright, F. A. S., Kayes, N. M., Worrall, L., \& McPherson, K. M. (2015). A conceptual review of engagement in healthcare and rehabilitation. Disability and Rehabilitation: An 
International, $\quad$ Multidisciplinary $\quad$ Journal, $\quad 37(8), \quad 643-654$. doi:10.3109/09638288.2014.933899

Chu, C., Bodell, L. P., Ribeiro, J. D., \& Joiner, T. E. (2015). Eating Disorder Symptoms and Suicidal Ideation: The Moderating Role of Disgust. Eur Eat Disord Rev, 23(6), 545552. doi:10.1002/erv.2373

Cherry, M. G., Taylor, P. J., Brown, S. L., Rigby, J. W., \& Sellwood, W. (2017). Guilt, shame and expressed emotion in carers of people with long-term mental health difficulties: A systematic review. Psychiatry Research, 249, 139-151. doi:10.1016/j.psychres.2016.12.056

Clark, D. M., \& Wells, A. (1995). A cognitive model of social phobia. In R. G. Heimberg, M. R. Liebowitz, D. A. Hope, \& F. R. Schneier (Eds.), Social phobia: Diagnosis, assessment, and treatment. (pp. 69-93). New York, NY, US: Guilford Press.

Colaizzi PF (1978). Psychological research as the phenomenologist views it. In: Valle RS, King M (eds). Existential phenomenological alternatives for psychology. Oxford University Press, New York.

Coughtrey, A. E., Shafran, R., Lee, M., \& Rachman, S. J. (2012). It's the feeling inside my head: A qualitative analysis of mental contamination in obsessive-compulsive disorder. Behavioural and Cognitive Psychotherapy, 40(2), 163-173. doi:10.1017/S1352465811000658

Coughtrey, A. E., Shafran, R., \& Rachman, S. J. (2014). The spontaneous decay and persistence of mental contamination: An experimental analysis. Journal of Behavior Therapy and Experimental Psychiatry, 45(1), 90-96. doi:10.1016/j.jbtep.2013.09.001

Derogatis, L. R., \& Spencer, P. M. (1993). Brief symptom inventory: BSI. Upper Saddle 
River, NJ: Pearson.

Dyer, A. S., Feldmann, R. E., Jr., \& Borgmann, E. (2015). Body-related emotions in posttraumatic stress disorder following childhood sexual abuse. Journal of Child Sexual Abuse: Research, Treatment, \& Program Innovations for Victims, Survivors, \& Offenders, 24(6), 627-640. doi:10.1080/10538712.2015.1057666

Ehlers, A., \& Clark, D. M. (2000). A cognitive model of posttraumatic stress disorder. Behaviour Research and Therapy, 38(4), 319-345. doi:10.1016/S00057967(99)00123-0

Espeset, E. M. S., Gulliksen, K. S., Nordbø, R. H. S., Skårderud, F., \& Holte, A. (2012). The link between negative emotions and eating disorder behaviour in patients with anorexia nervosa. European Eating Disorders Review, 20(6), 451-460. doi:10.1002/erv.2183

Fairbrother, N., \& Rachman, S. (2004). Feelings of mental pollution subsequent to sexual assault. Behaviour Research and Therapy, 42(2), 173-189. doi:10.1016/S00057967(03)00108-6

Foa, E. B. (1995). Posttraumatic stress diagnostic scale (PDS). Minneapolis: National Computer Systems.

Foa, E. B., Huppert, J. D., Leiberg, S., Langner, R., Kichic, R., Hajcak, G., \& Salkovskis, P. M. (2002). The Obsessive-Compulsive Inventory: Development and validation of a short version. Psychological Assessment, 14(4), 485-496. doi:10.1037/10403590.14.4.48

Fox, J. R., Grange, N., \& Power, M. J. (2015). Self-disgust in eating disorders: A review of the literature and clinical implications. In P.A. Powell, P. G. Overton, \& J. Simpson 
(Eds.), The revolting self: Perspectives on the psychological, social, and clinical implications of self-directed disgust (pp. 167-186). London: Karnac.

Garner, D. M., Olmsted, M. P., Bohr, Y., \& Garfinkel, P. E. (1982). The eating attitudes test: psychometric features and clinical correlates. Psychological Medicine, 12(04), 871878.

Garner, D. M., Olmsted, M. P., \& Polivy, J. (1983). The Eating Disorder Inventory: A measure of cognitive-behavioral dimensions of anorexia nervosa and bulimia. Anorexia nervosa: Recent developments in research, 3, 173-184.

Gilbert, P., Clarke, M., Hempel, S., Miles, J. N. V., \& Irons, C. (2004). Criticizing and reassuring oneself: An exploration of forms, styles and reasons in female students. British Journal of Clinical Psychology, 43(1), 31-50. doi:10.1348/014466504772812959

Gilbert, P., Durrant, R., \& McEwan, K. (2006). Investigating relationships between perfectionism, forms and functions of self-criticism, and sensitivity to put-down. Personality and Individual Differences, 41(7), 1299-1308. doi:10.1016/j.paid.2006.05.004

Gilbert, P., \& Procter, S. (2006). Compassionate mind training for people with high shame and self-criticism: overview and pilot study of a group therapy approach. Clinical Psychology \& Psychotherapy, 13(6), 353-379. doi:10.1002/cpp.507

Haidt, J., McCauley, C., \& Rozin, P. (1994). Individual differences in sensitivity to disgust: A scale sampling seven domains of disgust elicitors. Personality and Individual Differences, 16, 701-713. doi:10.1016/0191-8869(94)90212-7 
Hirao, K., \& Kobayashi, R. (2013). The relationship between self-disgust, guilt, and flow experience among Japanese undergraduates. Neuropsychiatric Disease and Treatment, 9, 985-988. doi:10.2147/ndt.s46895

Ille, R., Schoeggl, H., Kapfhammer, H. P., Arendasy, M., Sommer, M., \& Schienle, A. (2014). Self-disgust in mental disorders - symptom-related or disorder-specific? Comprehensive Psychiatry, 55(4), 938-943. doi:10.1016/j.comppsych.2013.12.020

Izard, C. E. (2007). Basic Emotions, Natural Kinds, Emotion Schemas, and a New Paradigm. Perspectives on Psychological Science, 2(3), 260-280. doi:10.1111/j.17456916.2007.00044.x

Izard, C. E. (2009). Emotion theory and research: highlights, unanswered questions, and emerging issues. Annual Review Of Psychology, 60, 1-25. doi:10.1146/annurev.psych.60.110707.163539

Jones, J. E., Robinson, J., Barr, W., \& Carlisle, C. (2008). Impact of exudate and odour from chronic venous leg ulceration. Nursing Standard, 22(45), 53-54, 56, 58 passim. doi:10.7748/ns2008.07.22.45.53.c6592

Jung, K., \& Steil, R. (2012). The feeling of being contaminated in adult survivors of childhood sexual abuse and its treatment via a two-session program of cognitive restructuring and imagery modification: A case study. Behavior Modification, 36(1), 67-86. doi:10.1177/0145445511421436

Jung, K., \& Steil, R. (2013). A randomized controlled trial on cognitive restructuring and imagery modification to reduce the feeling of being contaminated in adult survivors of childhood sexual abuse suffering from posttraumatic stress disorder. Psychotherapy and Psychosomatics, 82(4), 213-220. doi:10.1159/000348450 
Keltner, D., \& Buswell, B. N. (1996). Evidence for the distinctness of embarrassment, shame, and guilt: A study of recalled antecedents and facial expressions of emotion. Cognition and Emotion, 10(2), 155-171. doi:10.1080/026999396380312

Kleindienst, N., Priebe, K., Borgmann, E., Cornelisse, S., Krüger, A., Ebner-Priemer, U., \& Dyer, A. (2014). Body self-evaluation and physical scars in patients with borderline personality disorder: an observational study. Borderline Personality Disorder And Emotion Dysregulation, 1, 2-2. doi:10.1186/2051-6673-1-2.

Klonsky, E. D., \& Glenn, C. R. (2009). Assessing the functions of non-suicidal self-injury: Psychometric properties of the Inventory of Statements About Self-injury (ISAS). Journal of Psychopathology and Behavioral Assessment, 31(3), 215-219. doi:10.1007/s10862-008-9107-z

Kodaira, H. (2002). The relationships between self-discrepancies, the sense of superiority and competence, and self-disgust among female college students: Focusing on the relative importance between the ideal and ought selves. Japanese Journal of Experimental Social Psychology, 41(2), 165-174. doi:10.2130/jjesp.41.165

Kroenke, K., Spitzer, R. L., \& Williams, J. B. (2001). The Phq-9. Journal of general internal medicine, 16(9), 606-613. Downloaded from PsyInfo.

Lang, P. J. (1988). What are the data of emotion? In V. Hamilton, G. H. Bower, \& N. H. Frijda (Eds.), Cognitive perspectives on emotion and motivation. (pp. 173-191). New York, NY, US: Kluwer Academic/Plenum Publishers.

Larkin, W. \& Morrison, A. (2006). Trauma and Psychosis: New Directions for Theory and Therapy. Routledge: London.

Leaviss, J., \& Uttley, L. (2015). Psychotherapeutic benefits of compassion-focused therapy: 
an early systematic review. Psychological Medicine, 45(5), 927-945. doi:10.1017/S0033291714002141

Lovibond, P. F., \& Lovibond, S. H. (1995). The structure of negative emotional states: Comparison of the Depression Anxiety Stress Scales (DASS) with the Beck depression and anxiety inventories. Behaviour Research and Therapy, 33(3), 335-343. doi:10.1016/j.rbp.2012.05.003

McCarthy, S. (2008). Post-traumatic Stress Diagnostic Scale (PDS). Occupational Medicine (Oxford, England), 58(5), 379-379. doi:10.1093/occmed/kqn062

Millar, J. F. A., Salkovskis, P. M., \& Brown, C. (2016). Mental contamination in the 'dirty kiss': Imaginal betrayal or bodily fluids? Journal of Obsessive-Compulsive and Related Disorders, 8, 70-74. doi:10.1016/j.jocrd.2015.12.004

Neziroglu, F., Hickey, M., \& McKay, D. (2010). Psychophysiological and Self-Report Components of Disgust in Body Dysmorphic Disorder: The Effects of Repeated Exposure. International Journal of Cognitive Therapy, 3(1), 40-51. Downloaded from PsycInfo.

Olatunji, B. O. (2015). Selective effects of excessive engagement in health-related behaviours on disgust propensity. Cognition and Emotion, 29(5), 882-899. doi:10.1080/02699931.2014.951314

Olatunji, B. O., Cox, R., \& Kim, E. H. (2015). Self-disgust mediates the associations between shame and symptoms of bulimia and obsessive-compulsive disorder. Journal of 
Olatunji, B. O., Etzel, E. N., Tomarken, A. J., Ciesielski, B. G., \& Deacon, B. (2011). The effects of safety behaviors on health anxiety: An experimental investigation. Behaviour Research and Therapy, 49, 719-728. doi:10.1016/j.brat.2011.07.008

Osman, A., Bagge, C. L., Gutierrez, P. M., Konick, L. C., Kopper, B. A., \& Barrios, F. X. (2001). The Suicidal Behaviors Questionnaire--Revised (SBQ-R): Validation with clinical and nonclinical samples. Assessment, 8(4), 443-454. doi:10.1177/107319110100800409

Powell, P. A., Azlan, H. A., Simpson, J., \& Overton, P. G. (2016). The effect of disgust related side-effects on symptoms of depression and anxiety in people treated for cancer: a moderated mediation model. Journal of Behavioral Medicine, 39(4), 560573. doi:10.1007/s10865-016-9731-0

Powell, P. A., Overton, P. G., \& Simpson, J. (2014). The revolting self: an interpretative phenomenological analysis of the experience of self-disgust in females with depressive symptoms. Journal of Clinical Psychology, 70(6), 562-578. doi:10.1002/jclp.22049

Powell, P. A., Simpson, J., \& Overton, P. G. (2013). When disgust leads to dysphoria: a three-wave longitudinal study assessing the temporal relationship between self-disgust and depressive symptoms. Cognition and Emotion, 27(5), 900-913. doi:10.1080/02699931.2013.767223

Powell, P. A., Simpson, J., \& Overton, P. G. (2015a). An introduction to the revolting self: Self-disgust as an emotion schema. In P.A. Powell, P. G. Overton, \& J. Simpson (Eds.), The revolting self: Perspectives on the psychological, social, and clinical implications of self-directed disgust (pp. 1-24). London: Karnac. 
Powell, P. A., Simpson, J., \& Overton, P. G. (2015b). Reflections on the revolting self: A commentary and further directions. In P.A. Powell, P. G. Overton, \& J. Simpson (Eds.), The revolting self: Perspectives on the psychological, social, and clinical implications of self-directed disgust (pp. 243-255). London: Karnac.

Powell, P. A., Simpson, J., \& Overton, P. G. (2015c). Self-affirming trait kindness regulates disgust toward one's physical appearance. Body Image, 12, 98-107. doi:10.1016/j.bodyim.2014.10.006

Power, M., \& Dalgleish, T. (2016). Cognition and emotion: From order to disorder., 3rd ed. New York, NY, US: Psychology Press.

Preacher, K. J., \& Hayes, A. F. (2008). Assessing mediation in communication research. The Sage sourcebook of advanced data analysis methods for communication research, 1354. Downloaded from PsycInfo.

Rachman, S. (2004). Fear of contamination. Behaviour Research \& Therapy, 42(11), 1227 1255. doi:10.1016/j.brat.2003.10.009

Rachman, S. (2005). Vancouver obsessional compulsive inventory (VOCI-MC). Rachman Lab, University of British Columbia.

Rachman, S., \& Hodgson, R. (1974). I. Synchrony and desynchrony in fear and avoidance. Behaviour Research and Therapy, 12(4), 311-318. doi:10.1016/0005-7967(74)900059.

Ribeiro, J. D., Bodell, L., \& Joiner, T. E. (2012). Disgust with self, others, and world in suicidality. Poster Presented at the $46^{\text {th }}$ Annual Meeting of the Association for Behavioral and Cognitive Therapies, National Harbor, MD. 
Robins, R. W., \& Schriber, R. A. (2009). The self-conscious emotions: How are they experienced, expressed, and assessed? Social and Personality Psychology Compass, 3(6), 887-898. doi:10.1111/j.1751-9004.2009.00217.x

Rozin, P., Haidt, J., \& McCauley, C. R. (2008). Disgust. In M. Lewis, J. M. Haviland-Jones, \& L. F. Barrett (Eds.), Handbook of emotions, 3rd ed. (pp. 757-776). New York, NY, US: Guilford Press.

Rusch, N., Schulz, D., Valerius, G., Steil, R., Bohus, M., \& Schmahl, C. (2011). Disgust and implicit self-concept in women with borderline personality disorder and posttraumatic stress disorder. European Archive of Psychiatry and Clinical Neuroscience, 261(5), 369-376. doi:10.1007/s00406-010-0174-2

Salkovskis, P. M., Forrester, E., \& Richards, C. (1998). Cognitive-behavioural approach to understanding obsessional thinking. The British Journal of Psychiatry, 173(Suppl 35), 53-63.

Satoh, Y. (2001). Self-disgust and self-affirmation in university students. Japanese Journal of Educational Psychology, 49(3), 347-358. doi:10.5926/jjep1953.49.3_347

Scherer, K. R., \& Wallbott, H. G. (1994). Evidence for universality and cultural variation of differential emotion response patterning. Journal of Personality and Social Psychology, 66(2), 310-328. doi:10.1037/0022-3514.66.2.310

Schienle, A., Dietmaier, G., Ille, R., \& Leutgeb, V. (2010). A scale for the Assessment of Disgust sensitivity (SEE). ZEITSCHRIFT FUR KLINISCHE PSYCHOLOGIE UND PSYCHOTHERAPIE, 39(2), 80-86.

Schienle, A., Haas-Krammer, A., Schoggl, H., Kapfhammer, H. P., \& Ille, R. (2013). Altered state and trait disgust in borderline personality disorder. Journal of Nervous and 
Mental Disorders, 201(2), 105-108. doi:10.1097/NMD.0b013e31827f64da

Schienle, A., Ille, R., Sommer, M., \& Arendasy, M. (2014). Diagnosis of Self-Disgust in the Context of Depression. Verhaltenstherapie, 24(1), 15-20. doi:10.1159/000360189

Schienle, A., Leutgeb, V., \& Wabnegger, A. (2015). Symptom severity and disgust-related traits in borderline personality disorder: The role of amygdala subdivisions. Psychiatry Research, 232(3), 203-207. doi:10.1016/j.pscychresns.2015.04.002

Schienle, A., Schäfer, A., Stark, R., Walter, B., Franz, M., \& Vaitl, D. (2003). Disgust sensitivity in psychiatric disorders: a questionnaire study. The Journal Of Nervous And Mental Disease, 191(12), 831-834.

Schienle, A., Walter, B., Stark, R., \& Vaitl, D. (2002). A questionnaire for the assessment of disgust sensitivity. [Ein Fragebogen zur Erfassung der Ekelempfindlichkein (FEE)]. Zeitschrift Für Klinische Psychologie Und Psychotherapie, 31(2), 110-120. doi:10.1026/0084-5345.31.2.110

Schwab, D. P. (1980). Construct validity in organizational behavior. In L. L. Cummings \& B M. Staw (Eds.), Research in organizational behavior (Vol. 2) (pp. 3-43). Greenwich, CT.: JAI Press.

Simpson, J., Hillman, R., Crawford, T., \& Overton, P. G. (2010). Self-esteem and self-disgust both mediate the relationship between dysfunctional cognitions and depressive symptoms. Motivation and Emotion, 34(4), 399-406. doi:10.1007/s11031-010-9189-2

Smith, N. B., Steele, A. M., Weitzman, M. L., Trueba, A. F., \& Meuret, A. E. (2015). Investigating the role of self-disgust in nonsuicidal self-injury. Archives of Suicide Research, 19(1), 60-74. doi:10.1080/13811118.2013.850135 
Steil, R., Jung, K., \& Stangier, U. (2011). Efficacy of a two-session program of cognitive restructuring and imagery modification to reduce the feeling of being contaminated in adult survivors of childhood sexual abuse: A pilot study. Journal of Behavior Therapy and Experimental Psychiatry, 42(3), 325-329. doi:10.1016/j.jbtep.2011.01.008

Taylor, P. J., Hutton, P., \& Wood, L. (2015). Are people at risk of psychosis also at risk of suicide and self-harm? A systematic review and meta-analysis. Psychological Medicine, 45(5), 911-926. doi:10.1017/S0033291714002074.

Thompson, T., Dinnel, D. L., \& Dill, N. J. (2003). Development and validation of a Body Image Guilt and Shame Scale. Personality and Individual Differences, 34(1), 59-75. doi:10.1016/S0191-8869(02)00026-0

Tryon, W. W. (2005). Possible mechanisms for why desensitization and exposure therapy work. Clinical Psychology Review, 25(1), 67-95. doi:10.1016/j.cpr.2004.08.005

Van Manen, M. (2016). Researching lived experience: Human science for an action sensitive pedagogy. Routledge.

Van Overveld, W. J. M., de Jong, P. J., Peters, M. L., Cavanagh, K., \& Davey, G. C. L. (2006). Disgust propensity and disgust sensitivity: Separate constructs that are differentially related to specific fears. Personality and Individual Differences, 41(7), 1241-1252. doi:10.1016/j.paid.2006.04.021

Weathers FW, Blake DD, Schnurr PP, Kaloupek DG, Marx BP et al. (2013). The Life Events Checklist for DSM-5 (LEC-5). Instrument available from the National Center for PTSD at www.ptsd.va.gov 
Weathers F, Litz B, Keane T, Palmieri T, Marx B.P, Schnurr P. (2013). The PTSD Checklist for DSM-5 (PCL-5). Scale available from the National Center for PTSD at www.ptsd.va.gov.

Weissman, A. N. (1980). Assessing depressogenic attitudes: A validation study. Paper presented at the 51st annual meeting of the Eastern Psychological Association, Hartford, Connecticut.

Wells, A. (1999). A metacognitive model and therapy for generalized anxiety disorder. Clinical Psychology \& Psychotherapy, 6(2), 86-95. Downloaded from PscyInfo.

Williams, J. W., Plassman, B. L., Burke, J., \& Benjamin, S. (2010). Preventing Alzheimer's disease and cognitive decline. Evidence Report/Technology Assessment (193), 1-727. Downloaded from PsycInfo.

Young, J. E. (1999). Cognitive therapy for personality disorders: A schema-focused approach., 3rd ed. Sarasota, FL, US: Professional Resource Press/Professional Resource Exchange.

Young, J. E., Klosko, J. S., \& Weishaar, M. E. (2003). Schema therapy: A practitioner's guide. New York, NY, US: Guilford Press.

Zigmond, A. S., \& Snaith, R. P. (1983). The Hospital Anxiety and Depression Scale. Acta Psychiatrica Scandinavica, 67(6), 361-370. doi:10.1111/j.1600-0447.1983.tb09716 


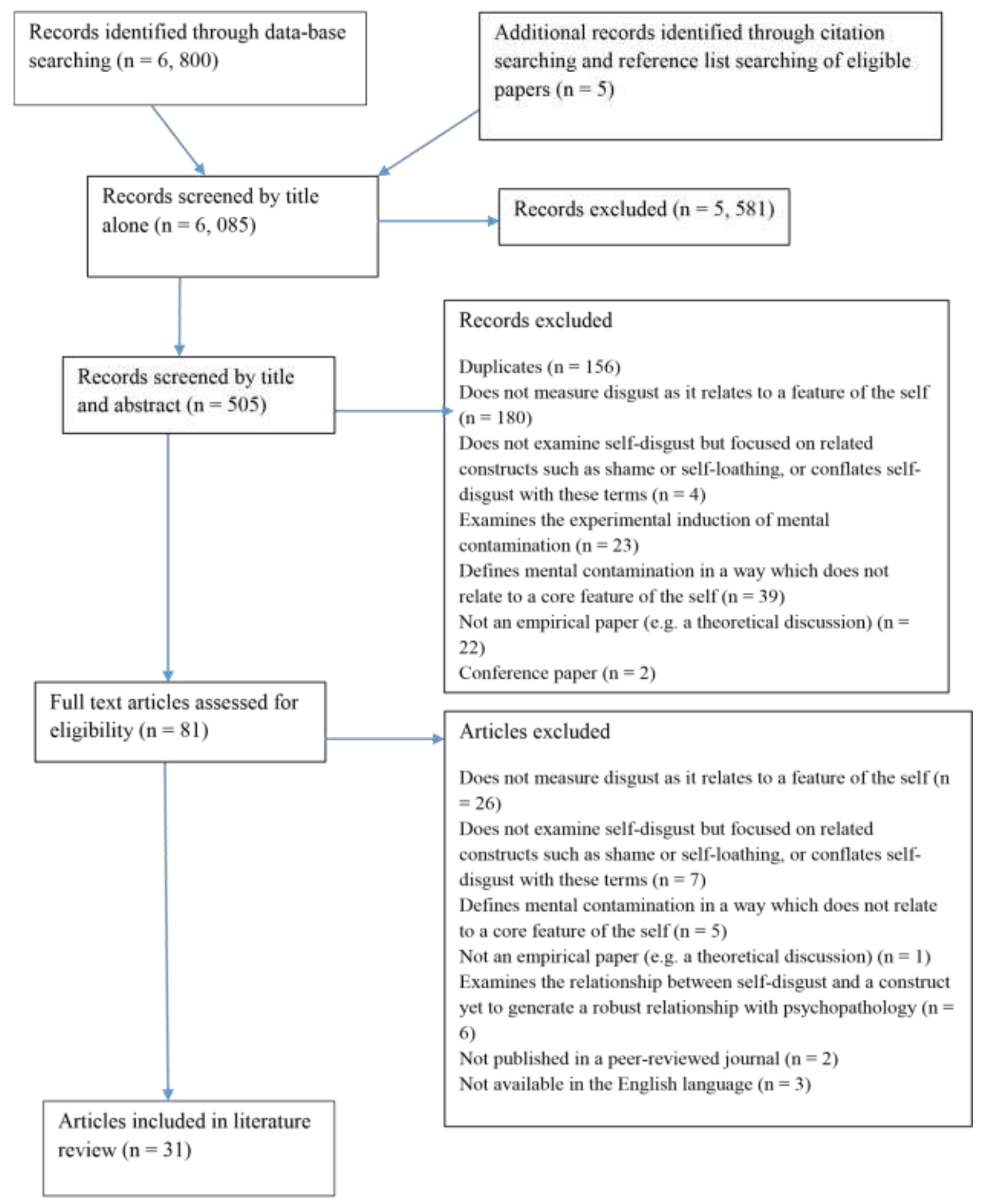

Figure 1. Flow diagram documenting search strategy 
Table 1. Assessment of risk of

bias

\begin{tabular}{|c|c|c|c|c|c|c|c|c|c|}
\hline Authors & $\begin{array}{l}\text { Unbiased } \\
\text { selection } \\
\text { of cohort? }\end{array}$ & $\begin{array}{l}\text { Sample } \\
\text { size } \\
\text { calculation } \\
?\end{array}$ & $\begin{array}{l}\text { Adequate } \\
\text { description } \\
\text { of cohort? }\end{array}$ & $\begin{array}{ll}\text { Validated } & \\
\text { method for } \\
\text { assessing self- } \\
\text { disgust? }\end{array}$ & $\begin{array}{l}\text { Validated method } \\
\text { for assessing } \\
\text { mental health } \\
\text { difficulty? }\end{array}$ & $\begin{array}{l}\text { Outcome } \\
\text { assessors blind to } \\
\text { predictor } \\
\text { variables? }\end{array}$ & $\begin{array}{l}\text { Missing } \\
\text { data } \\
\text { minimal? }\end{array}$ & $\begin{array}{l}\text { Confounders } \\
\text { controlled } \\
\text { for? }\end{array}$ & $\begin{array}{l}\text { Appropriate } \\
\text { analyses? }\end{array}$ \\
\hline $\begin{array}{|cc|}\text { Abdul-Hamid, } & \text { Denman } \quad \& \\
\text { Dudas (2014) } & \end{array}$ & Partial & No & Yes & Partial & Partial & $\mathrm{n} / \mathrm{s}$ & Yes & Partial & Yes \\
\hline $\begin{array}{l}\text { Azlan, Overton, Simpson \& } \\
\text { Powell (2017) }\end{array}$ & Yes & No & Yes & Yes & Yes & $\mathrm{n} / \mathrm{s}$ & $\mathrm{n} / \mathrm{s}$ & Yes & Yes \\
\hline Bachtelle \& Pepper (2015) & Yes & No & Yes & Yes & Partial & $\mathrm{n} / \mathrm{s}$ & $\mathrm{n} / \mathrm{s}$ & No & Partial \\
\hline \begin{tabular}{|l|} 
Badour, $\quad$ Bown, Adams, \\
Bunaciu, Feldner (2012)
\end{tabular} & $\mathrm{n} / \mathrm{s}$ & No & Yes & Partial & Yes & $\mathrm{n} / \mathrm{a}$ & $\mathrm{n} / \mathrm{s}$ & Partial & Yes \\
\hline $\begin{array}{l}\text { Badour, Feldner, Blumenthal } \\
\text { \& Bujarski (2013) }\end{array}$ & $\mathrm{n} / \mathrm{s}$ & No & Yes & Partial & Yes & $\mathrm{n} / \mathrm{s}$ & $\mathrm{n} / \mathrm{s}$ & Partial & Yes \\
\hline $\begin{array}{l}\text { Badour, Ojserkis, McKay \& } \\
\text { Feldner (2014) }\end{array}$ & $\mathrm{n} / \mathrm{s}$ & No & Yes & Partial & Yes & $\mathrm{n} / \mathrm{s}$ & $\mathrm{n} / \mathrm{s}$ & Partial & Yes \\
\hline Bornholt, Brake et al. (2005) & $\mathrm{n} / \mathrm{s}$ & No & Yes & Partial & Partial & $\mathrm{n} / \mathrm{s}$ & $\mathrm{n} / \mathrm{s}$ & Partial & Yes \\
\hline \begin{tabular}{|cccc}
$\begin{array}{c}\text { Bowyer, } \\
(2014)\end{array}$ & Wallace \& & Lee \\
\end{tabular} & No & $\mathrm{n} / \mathrm{a}$ & Yes & Partial & Yes & No & $\mathrm{n} / \mathrm{a}$ & No & Yes \\
\hline $\begin{array}{l}\text { Brake, Rojas, Badour, Dutton } \\
\& \text { Feldner (2017) }\end{array}$ & Yes & No & Yes & Yes & Yes & $\mathrm{n} / \mathrm{s}$ & $\mathrm{n} / \mathrm{s}$ & Partial & Yes \\
\hline $\begin{array}{l}\text { Chu, Bodell, Ribeiro \& Joiner } \\
(2015)\end{array}$ & Partial & Yes & Yes & Yes & Yes & $\mathrm{n} / \mathrm{s}$ & Yes & Partial & Yes \\
\hline Dudas et al. (2017) & Partial & No & Partial & Yes & Partial & No & $\mathrm{n} / \mathrm{s}$ & Partial & Yes \\
\hline $\begin{array}{l}\text { Dyer, Feldman \& Borgmann } \\
(2015)\end{array}$ & Partial & No & Partial & Partial & Partial & No & $\mathrm{n} / \mathrm{s}$ & No & Yes \\
\hline
\end{tabular}




\begin{tabular}{|c|c|c|c|c|c|c|c|c|c|}
\hline $\begin{array}{l}\text { Espeset, Gulliksen, Nordbo, } \\
\text { Skarderud \& Holte (2012) }\end{array}$ & Yes & $\mathrm{n} / \mathrm{a}$ & Yes & Yes & Yes & $\mathrm{n} / \mathrm{a}$ & $\mathrm{n} / \mathrm{a}$ & $\mathrm{n} / \mathrm{a}$ & Yes \\
\hline Ille et al. (2014) & Partial & No & Partial & Yes & Yes & $\mathrm{n} / \mathrm{s}$ & $\mathrm{n} / \mathrm{s}$ & Partial & Yes \\
\hline Jones et al. (2008) & Yes & No & Yes & Yes & Yes & $\mathrm{n} / \mathrm{a}$ & $\mathrm{n} / \mathrm{a}$ & $\mathrm{n} / \mathrm{a}$ & Partial \\
\hline Jung \& Steil (2013) & No & Yes & Yes & Partial & Yes & $\mathrm{n} / \mathrm{s}$ & Yes & No & Yes \\
\hline Jung \& Steil (2012) & No & n/a & Yes & Partial & Yes & $\mathrm{n} / \mathrm{s}$ & Yes & No & Yes \\
\hline $\begin{array}{l}\text { Laffan, Millar, Salkovskis \& } \\
\text { Whitby (2015) }\end{array}$ & Yes & Yes & Yes & Yes & Yes & $\mathrm{n} / \mathrm{s}$ & $\mathrm{n} / \mathrm{s}$ & No & Yes \\
\hline Olatunji (2015) & Partial & Yes & Partial & Yes & Partial & No & $\mathrm{n} / \mathrm{s}$ & Partial & Yes \\
\hline Olatunji, Cox \& Kim (2015) & Partial & No & Yes & Yes & Yes & $\mathrm{n} / \mathrm{s}$ & No & Yes & Yes \\
\hline $\begin{array}{l}\text { Overton, Markland, Simpson, } \\
\text { Taggart \& Bagshaw (2008) }\end{array}$ & Partial & Yes & Partial & Yes & Yes & $\mathrm{n} / \mathrm{s}$ & $\mathrm{n} / \mathrm{s}$ & Partial & Yes \\
\hline $\begin{array}{l}\text { Powell, Azlan, Simpson \& } \\
\text { Overton (2016) }\end{array}$ & Yes & No & Yes & Yes & Yes & $\mathrm{n} / \mathrm{s}$ & Yes & Partial & Yes \\
\hline $\begin{array}{l}\text { Powell, Overton \& Simpson } \\
(2014)\end{array}$ & No & n/a & Yes & Yes & Yes & $\mathrm{n} / \mathrm{a}$ & $\mathrm{n} / \mathrm{a}$ & n/a & Yes \\
\hline $\begin{array}{l}\text { Powell, Simpson \& Overton } \\
(2013)\end{array}$ & Partial & No & Yes & Yes & Yes & $\mathrm{n} / \mathrm{s}$ & Yes & Partial & Yes \\
\hline $\begin{array}{l}\text { Nexiroglu, Hickey \& McKay } \\
(2010)\end{array}$ & Partial & No & Partial & Partial & Partial & $\mathrm{n} / \mathrm{s}$ & Yes & No & Yes \\
\hline Rusch et al. (2011) & Partial & No & Yes & Partial & Partial & $n / s$ & $\mathrm{n} / \mathrm{s}$ & Partial & Yes \\
\hline \begin{tabular}{|l} 
Schienle, $\quad$ Leutgeb \& \\
Wabnegger (2015)
\end{tabular} & Partial & No & Partial & Yes & Partial & $\mathrm{n} / \mathrm{s}$ & $\mathrm{n} / \mathrm{s}$ & No & Yes \\
\hline $\begin{array}{l}\text { Schienle, Haas-Krammer, } \\
\text { Schoggle \& Ille (2013) }\end{array}$ & Partial & No & Yes & Yes & Partial & $\mathrm{n} / \mathrm{s}$ & $\mathrm{n} / \mathrm{s}$ & No & Yes \\
\hline
\end{tabular}




\begin{tabular}{|l|l|l|l|l|l|l|l|l|l|}
\hline $\begin{array}{l}\text { Simpson, Hillman, Crawford \& } \\
\text { Overton (2010) }\end{array}$ & Yes & Yes & Yes & Yes & Yes & Yes & & Yes \\
\hline $\begin{array}{l}\text { Smith, Steil, Weitzman, Trueba } \\
\text { \& Meuret (2015) }\end{array}$ & Partial & No & Yes & Yes & Yes & n/s & Partial & Yes \\
\hline Steil, Jung \& Stangier (2011) & Partial & No & Yes & Partial & Yes & n/s & Yes & No & Yes \\
\hline
\end{tabular}

$\mathrm{n} / \mathrm{s}$ - not specified

n/a - not applicable 
Table 2: Study characteristics

\begin{tabular}{|c|c|c|c|c|c|c|}
\hline Authors & Research question & Design & Sample & Key measures & Analytic strategy & Key findings \\
\hline $\begin{array}{l}\text { Abdul-Hamid, } \\
\text { Denman \& } \\
\text { Dudas (2014) }\end{array}$ & $\begin{array}{l}\text { Examined Self-Relevant } \\
\text { Disgust and Self-Harm } \\
\text { Urges in Patients with } \\
\text { Borderline Personality } \\
\text { Disorder and Depression. } \\
\text { Predicted that overall disgust } \\
\text { levels would be higher in } \\
\text { BPD group, and that } \\
\text { increases in self-disgust } \\
\text { would predict increases in } \\
\text { self-harm urges. }\end{array}$ & $\begin{array}{l}\text { Quasiexperimental } \\
\text { between groups } \\
\text { design, in which } \\
\text { self-harm urges } \\
\text { were measured } \\
\text { across groups } \\
\text { following task to } \\
\text { induce selfdisgust. }\end{array}$ & $\begin{array}{l}17 \text { BPD patients, } \\
27 \text { MDD } \\
\text { patients, } 25 \\
\text { healthy controls } \\
\text { All women }\end{array}$ & $\begin{array}{l}\text { Task - write a 3-minute narrative } \\
\text { focused on negative aspects of the self, } \\
\text { then a 3-minute narrative on negative } \\
\text { aspects of the body } \\
\text { Visual analogue measures of disgust } \\
\text { taken before and after both the person } \\
\text { and body focused tasks } \\
\text { Changes in self-harm urges after both } \\
\text { tasks } \\
\text { Narratives coded for the label of } \\
\text { emotions }\end{array}$ & $\begin{array}{l}\text { Krushkav-Wallis and } \\
\text { Mann-Whitney U }\end{array}$ & $\begin{array}{l}\text { The BPD group had higher levels of post-task disgust in the } \\
\text { PERSON task (writing a piece focused on their own } \\
\text { personality) than healthy volunteers. } \\
\text { The BPD group had higher levels of post-task disgust in the } \\
\text { BODY task (writing a piece on their emotions towards their } \\
\text { body) than both the MDD group and the healthy controls. } \\
\text { Changes in self-harm levels were associated with disgust } \\
\text { narrative labels on a whole sample level. } \\
\text { Changes in disgust levels in people with MDD in the } \\
\text { PERSON task was associated with increased urges to } \\
\text { selfharm. }\end{array}$ \\
\hline $\begin{array}{l}\text { Azlan, Overton, } \\
\text { Simpson \& } \\
\text { Powell (2017) }\end{array}$ & $\begin{array}{l}\text { Are levels of self-disgust } \\
\text { higher in people with cancer } \\
\text { compared to matched } \\
\text { controls? } \\
\text { Do higher levels of } \\
\text { selfdisgust in both cancer } \\
\text { patients and controls predict } \\
\text { higher levels of depression } \\
\text { and anxiety? }\end{array}$ & $\begin{array}{l}\text { Cross-sectional } \\
\text { correlational }\end{array}$ & $\begin{array}{l}107 \text { cancer patients } \\
\text { with } \\
\text { heterogeneous } \\
\text { cancer dx ( } 72 \% \\
\text { women), } \\
\text { compared to } 107 \\
\text { controls matched } \\
\text { on age and gender }\end{array}$ & $\begin{array}{ll}- & \text { Self-disgust scale (Overton et al., 2008) } \\
- & \text { Hospital Anxiety and Depression Scale } \\
& \text { (HADS; Zigmond \& Snaith, 1983) }\end{array}$ & $\begin{array}{l}\text { Logistic regression } \\
\text { categorising people in } \\
\text { to cancer vs noncancer } \\
\text { categories based on } \\
\text { disgust } \\
\text { scores } \\
\text { Multiple regression to } \\
\text { examine relationships } \\
\text { between self-disgust } \\
\text { and depression/anxiety }\end{array}$ & $\begin{array}{l}\text { Cancer patients were } 1.13 \text { times as likely to exhibit higher } \\
\text { physical self-disgust than control patients. } \\
\text { Both physical and behaviour self-disgust significantly } \\
\text { correlated with anxiety and depression. } \\
\text { Multiple regression analysis indicated that physical and } \\
\text { behavioural self-disgust significantly predicted anxiety in } \\
\text { cancer patients, but only behavioural } \\
\text { controls. } \\
\text { Physical (but not behavioural) self-disgust significantly } \\
\text { predicted depression in both cancer patients and controls } \\
\text { Behavioural self-disgust had only weak relationships to } \\
\text { depression in both groups. }\end{array}$ \\
\hline $\begin{array}{l}\text { Bachtelle \& } \\
\text { Pepper (2015) }\end{array}$ & $\begin{array}{l}\text { What emotions influence } \\
\text { scar-related growth or shame } \\
\text { in individuals who engage in } \\
\text { non-suicidal self-injury } \\
\text { (NSSI)? }\end{array}$ & $\begin{array}{l}\text { Cross-sectional } \\
\text { correlational }\end{array}$ & $\begin{array}{l}49 \text { college } \\
\text { students ( } 73 \% \\
\text { female) with scars } \\
\text { from NSSI, } \\
\text { recruited from a } \\
\text { broader sample }\end{array}$ & $\begin{array}{l}\text { Deliberate Self-Harm Inventory (DSHI; } \\
\text { Gratz, 2001), with an additional qst about } \\
\text { future likelihood of self-harm. } \\
\text { Self-Disgust Scale (Overton et al., 2008) } \\
\text { Differential Emotions Scale IV (DES-IV-A; } \\
\text { Izard et al., } \\
\text { 1993) }\end{array}$ & Correlational analysis & $\begin{array}{l}\text { Self-disgust was significantly negatively correlated with } \\
\text { post-traumatic growth. } \\
\text { Self-disgust was also significantly positively correlated with } \\
\text { scar-related shame. }\end{array}$ \\
\hline Badour, Bown, & Peri-traumatic fear, self and & Cross-sectional & Community & Rating of between 0 and 100 on the & Hierarchical multiple & Peritraumatic self-focused disgust significantly predicted \\
\hline
\end{tabular}




\begin{tabular}{|c|c|c|c|c|c|c|}
\hline $\begin{array}{l}\text { Adams, } \\
\text { Bunaciu, } \\
\text { Feldner (2012) }\end{array}$ & $\begin{array}{l}\text { other-focused disgust in } \\
\text { predicting development of } \\
\text { PTSD or contaminationbased } \\
\text { OCD }\end{array}$ & correlational & $\begin{array}{l}\text { sample of } 49 \text { adult } \\
\text { women with a } \\
\text { history of } \\
\text { interpersonal } \\
\text { traumatic } \\
\text { victimization ( } 27 \\
\text { sexual assault, } 22 \\
\text { physical assault). }\end{array}$ & $\begin{array}{l}\text { experience of peri-traumatic self-focused } \\
\text { disgust, perpetrator-focused disgust and fear. } \\
\text { Obsessive-Compulsive Inventory-Revised } \\
\text { (OCI-R; Foa et al., 2002). } \\
\text { Clinician-Administered PTSD Scale (CAPS; } \\
\text { Blake et al., 1995) }\end{array}$ & regression & $\begin{array}{l}\text { contamination-based OCD but not PTSD. } \\
\text { Peritraumatic fear and other-focused discussed significantly } \\
\text { predicted PTSD }\end{array}$ \\
\hline $\begin{array}{l}\text { Badour, } \\
\text { Feldner, } \\
\text { Blumenthal \& } \\
\text { Bujarski (2013) }\end{array}$ & $\begin{array}{l}\text { Is the relationship between } \\
\text { disgust sensitivity and PTSD } \\
\text { following sexual trauma } \\
\text { mediated by mental } \\
\text { contamination? }\end{array}$ & $\begin{array}{l}\text { Cross-sectional } \\
\text { correlational }\end{array}$ & $\begin{array}{l}\text { Community } \\
\text { sample of } 38 \\
\text { women with a } \\
\text { history of at least } \\
\text { one traumatic } \\
\text { sexual assault, } \\
\text { recruited from a } \\
\text { broader study }\end{array}$ & $\begin{array}{l}\text { Disgust Propensity and Sensitivity } \\
\text { ScaleRevised (DPSS-R; van Overveld et al., } \\
\text { 2006) } \\
\text { Sexual Assault-Related Mental } \\
\text { Contamination scale (Fairbrother and } \\
\text { Rachman } \\
\text { 2004) } \\
\text { Clinician-Administered PTSD Scale } \\
\text { (CAPS; Blake et al. 1995), }\end{array}$ & $\begin{array}{l}\text { PROCESS (based on } \\
\text { linear regression } \\
\text { models and Sobel's } \\
\text { test of the indirect } \\
\text { effect) }\end{array}$ & $\begin{array}{l}\text { Both disgust-sensitivity and sexual assault related mental } \\
\text { contamination were significantly correlated with } \\
\text { posttraumatic stress symptom severity. } \\
\text { Disgust sensitivity predicted post-traumatic stress through its } \\
\text { relationship with mental contamination. }\end{array}$ \\
\hline $\begin{array}{l}\text { Badour, } \\
\text { Ojserkis, } \\
\text { McKay \& } \\
\text { Feldner (2014) }\end{array}$ & $\begin{array}{l}\text { Evaluated the degree to which } \\
\text { self-focused and perpetrator- } \\
\text { focused disgust were } \\
\text { predictive of mental } \\
\text { contamination following } \\
\text { sexual trauma }\end{array}$ & $\begin{array}{l}\text { Cross-sectional } \\
\text { correlational }\end{array}$ & $\begin{array}{l}72 \text { women } \\
\text { recruited from the } \\
\text { community with a } \\
\text { history of sexual } \\
\text { trauma }\end{array}$ & $\begin{array}{l}\text { Rating of between } 0 \text { and } 100 \text { on the } \\
\text { experience of peri-traumatic self-focused } \\
\text { disgust, perpetrator-focused disgust and fear. } \\
\text { Vancouver Obsessional Compulsive } \\
\text { Inventory-Mental Contamination Scale } \\
\text { (VOCI-MC; Rachman, 2005). }\end{array}$ & $\begin{array}{l}\text { Hierarchical } \\
\text { regression analysis. }\end{array}$ & $\begin{array}{l}\text { Peri-traumatic self-focused disgust, but not peri-traumatic } \\
\text { perpetrator-focused disgust or fear, was significantly } \\
\text { associated with mental contamination following sexual } \\
\text { trauma. }\end{array}$ \\
\hline $\begin{array}{l}\text { Bornholt, Brake } \\
\text { et al. (2005) }\end{array}$ & $\begin{array}{l}\text { What self-concepts are } \\
\text { employed by adolescent girls } \\
\text { to evaluate their bodies? }\end{array}$ & Cross-sectional & $\begin{array}{l}141 \text { adolescent } \\
\text { girls from across } \\
\text { the weight range, } \\
\text { including } 28 \text { girls } \\
\text { currently } \\
\text { hospitalized with } \\
\text { anorexia. }\end{array}$ & $\begin{array}{l}\text { Specially designed task in which participants } \\
\text { visualised their bodies and circled the } \\
\text { emotions they felt. }\end{array}$ & T-tests & $\begin{array}{l}\text { Comparison of the anorexic group with a low-BMI control } \\
\text { group drawn from the schoolgirl sample indicated that } \\
\text { anorexic girls felt significantly more disgust towards their } \\
\text { own bodies. }\end{array}$ \\
\hline $\begin{array}{l}\text { Bowyer, } \\
\text { Wallace \& Lee } \\
\text { (2014) }\end{array}$ & $\begin{array}{l}\text { Case study examining the } \\
\text { efficacy of a } \\
\text { compassionfocused approach } \\
\text { to reduce feelings of self- } \\
\text { disgust in } \\
\text { enhancing trauma-focused } \\
\text { CBT }\end{array}$ & $\begin{array}{l}\text { Single-case } \\
\text { repeated measures }\end{array}$ & $\begin{array}{l}\text { A } 17 \text { year old girl } \\
\text { who had suffered a } \\
\text { sexual assault } 5 \\
\text { years previously } \\
\text { and was } \\
\text { undergoing TF- } \\
\text { CBT }\end{array}$ & $\begin{array}{l}\text { Post Traumatic Diagnostic Scale (Foa, 1995) } \\
\text { The Beck } \\
\text { Depression Inventory (BDI-II; Beck, Steer } \\
\text { and Brown, 1996) } \\
\text { The Forms of } \\
\text { Self-Criticizing/Attacking and } \\
\text { SelfReassuring Scale (FSCRS; Gilbert, Clark, } \\
\text { Hempel, Miles } \\
\text { and Irons, 2004) }\end{array}$ & $\begin{array}{l}\text { Descriptive comparison } \\
\text { of pre and post test } \\
\text { measures and client } \\
\text { feedback. }\end{array}$ & $\begin{array}{l}\text { PTSD symptom severity changed from severe to mild. } \\
\text { Depression levels declined from moderate-severe to normal. } \\
\text { Clinically significant decreases in how much the client } \\
\text { expressed shame and disgust towards herself. }\end{array}$ \\
\hline
\end{tabular}




\begin{tabular}{|c|c|c|c|c|c|c|}
\hline $\begin{array}{l}\text { Brake, Rojas, } \\
\text { Badour, Dutton } \\
\& \quad \text { Feldner } \\
(2017)\end{array}$ & $\begin{array}{l}\text { Is the relationship between } \\
\text { PTSD and suicide risk } \\
\text { mediated by self-disgust? } \\
\text { Is a different mediating } \\
\text { relationship present for } \\
\text { individual PTSD symptom } \\
\text { clusters? }\end{array}$ & Cross-sectional & $\begin{array}{l}347 \text { young adults } \\
(66 \% \text { female) who } \\
\text { have experienced } \\
\text { at least } 1 \\
\text { traumatic event as } \\
\text { defined by DSM- } \\
\text { V criteria }\end{array}$ & $\begin{array}{l}\text { Self-Disgust Scale (SDS; Overton et al., } \\
\text { 2008) } \\
\text { PHQ-9 (Kroenke et al., 2001) } \\
\text { Suicide Behaviours Questionnaire- Revised } \\
\text { (Osman, 2001) } \\
\text { Post-Traumatic Checklist for DSM-V } \\
\text { (Weathers, Litz et al., 2013) } \\
\text { Life Events Checklist (LEC-5; Weathers et }\end{array}$ & $\begin{array}{l}\text { Multiple regression } \\
\text { with boot-strapped } \\
\text { confidence intervals }\end{array}$ & $\begin{array}{l}\text { The relationship between total PTSD symptoms and suicide } \\
\text { risk was mediated by the "disgusting self" scale of the SDS. } \\
\text { Alt hough PTSD symptoms significantly predicted the } \\
\text { "disgusting ways" scale, this scale in turn did not predict } \\
\text { suicide risk. } \\
\text { The "disgusting self" scale also mediated the relationship } \\
\text { between the re-experiencing, negative mood/cognitions, and }\end{array}$ \\
\hline & & & & al., 2013) & & $\begin{array}{l}\text { avoidance PTSD symptom clusters and suicide risk. } \\
\text { However, there was no relationship between alterations in } \\
\text { arousal and the "disgusting self" scale, although there was a } \\
\text { relationship to the "disgusting ways" scale. }\end{array}$ \\
\hline $\begin{array}{l}\text { Chu, Bodell, } \\
\text { Ribeiro \& } \\
\text { Joiner (2015) }\end{array}$ & $\begin{array}{l}\text { Does disgust moderate the } \\
\text { relationship between eating } \\
\text { disorders and suicidal } \\
\text { ideation? }\end{array}$ & $\begin{array}{l}\text { Cross-sectional } \\
\text { correlational }\end{array}$ & $\begin{array}{l}341 \text { young adults } \\
(66 \% \text { women }) \\
\text { recruited from a } \\
\text { university }\end{array}$ & $\begin{array}{l}\text { Eating disorder inventory (Garner, } \\
\text { Olmstead, \& Polivy, 1983). } \\
\text { Disgust with life scale (Ribeiro, Bodell, \& } \\
\text { Joiner, 2012). } \\
\text { Disgust propensity and sensitivity } \\
\text { scalerevised (Fergus \& } \\
\text { Valentiner, 2009) } \\
\text { Beck scale for suicide ideation (Beck \& } \\
\text { Steer, 1991). }\end{array}$ & $\begin{array}{l}\text { Multi-variate linear } \\
\text { regression analysis }\end{array}$ & $\begin{array}{l}\text { Eating disorder symptoms and body dissatisfaction were } \\
\text { associated with suicidal ideation at high levels of disgust } \\
\text { towards the self and the world, but were not related at low } \\
\text { levels of disgust at self/world. }\end{array}$ \\
\hline $\begin{array}{ll}\text { Dudas } & \text { et } \\
& \text { al. } \\
\text { (2017) } & \end{array}$ & $\begin{array}{l}\text { Do patients with BPD } \\
\text { selfreport more self-disgust } \\
\text { than controls? } \\
\text { Is this connected with } \\
\text { differential connectivity in } \\
\text { emotion processing neural } \\
\text { regions? }\end{array}$ & Case control & $\begin{array}{l}14 \text { women with a } \\
\text { BPD diagnosis } \\
\text { and } 14 \text { female } \\
\text { controls }\end{array}$ & $\begin{array}{l}\text { Self-Disgust Scale (Overton et al., 2008) } \\
\text { Neuro-imaging techniques }\end{array}$ & T-test & $\begin{array}{l}\text { BPD subjects compared to controls scored significantly } \\
\text { higher on the Self-disgust Scale (BPD } 62.36[10.4] \text {; } \\
\text { NC: } 21.67[7.4] \mathrm{p}<0.001) \text {. } \\
\text { BPD showed abnormal patterns of activation, habituation } \\
\text { and connectivity in regions linked to emotion regulation. }\end{array}$ \\
\hline $\begin{array}{l}\text { Dyer, Feldman } \\
\& \quad \text { Borgmann } \\
(2015)\end{array}$ & $\begin{array}{l}\text { What emotions are triggered } \\
\text { by the body areas associated } \\
\text { with sexual trauma? Do } \\
\text { PTSD\&BPD patients exhibit } \\
\text { more negative body-related } \\
\text { images than controls? Do } \\
\text { PTSD patients rate } \\
\text { traumaassociated parts of the } \\
\text { body more aversively? }\end{array}$ & $\begin{array}{l}\text { Between-groups } \\
\text { design comparing } \\
\text { Dx groups to } \\
\text { healthy controls } \\
\text { (PTSD\&BPD; } \\
\text { PTSD only; BPD } \\
\text { only; healthy } \\
\text { controls) }\end{array}$ & $\begin{array}{l}23 \text { patients with } \\
\text { PTSD after CSA } \\
25 \text { participants } \\
\text { with BPD but not } \\
\text { CSA } \\
22 \text { patients with } \\
\text { PTSD after CSA } \\
\text { \& BPD } \\
27 \text { healthy } \\
\text { controls } \\
\text { All women. }\end{array}$ & $\begin{array}{l}\text { Modified version of the Survey of Body } \\
\text { Areas (SBA; } \\
\text { Kleindienst et al., 2014) } \\
\text { Disgust sensitivity scale (dss) (Schienle, } \\
\text { Walt, Stark \& Vaitl, 2002) } \\
\text { Body image guilt and shame scale (bigss; } \\
\text { Thompson, Dinnel, \& Dill, 2003) }\end{array}$ & $\begin{array}{l}\text { Non-parametric } \\
\text { Kruskal-Wallis test } \\
\text { Mann-Whitney U }\end{array}$ & $\begin{array}{l}\text { All negative body-related emotions were significantly } \\
\text { higher in the patient groups than in the control groups. } \\
\text { Significantly more feelings of disgust were observed in the } \\
\text { PTSD\&BPD group than in the BPD group alone. Both } \\
\text { PTSD groups reported significantly more } \\
\text { traumaassociated body areas than any of the other groups. } \\
\text { Trauma-associated areas were rated significantly more } \\
\text { negatively than non-trauma associated areas. }\end{array}$ \\
\hline
\end{tabular}




\begin{tabular}{|c|c|c|c|c|c|c|}
\hline $\begin{array}{l}\text { Espeset, } \\
\text { Gulliksen, } \\
\text { Nordbo, } \\
\text { Skarderud \& } \\
\text { Holte (2012) }\end{array}$ & $\begin{array}{l}\text { Qualitative exploration of the } \\
\text { link between negative } \\
\text { emotions and eating disorder } \\
\text { behaviour in people with } \\
\text { anorexia - how do patients } \\
\text { with Anorexia Nervosa } \\
\text { manage negative emotions, } \\
\text { and how do they link this to } \\
\text { anorexic behaviours? }\end{array}$ & $\begin{array}{l}\text { Qualitative } \\
\text { interviewing }\end{array}$ & $\begin{array}{l}14 \text { women, aged } \\
19-39, \text { diagnosed } \\
\text { with anorexia }\end{array}$ & Focused interview strategy & Grounded theory & $\begin{array}{l}\text { Participants exhibited high levels of self-disgust and fear of } \\
\text { becoming fat. Disgust was managed predominantly by } \\
\text { avoidance. }\end{array}$ \\
\hline \multirow[t]{2}{*}{ Ille et al. (2014) } & $\begin{array}{l}\text { Do participants with "mental } \\
\text { disorders" have higher levels } \\
\text { of self-disgust compared to } \\
\text { "healthy" controls? }\end{array}$ & Case control & $\begin{array}{l}112 \text { patients with } \\
\text { various diagnoses } \\
\text { (eating disorders, } \\
\text { borderline }\end{array}$ & $\begin{array}{l}\text { Questionnaire for the Assessment of } \\
\text { SelfDisgust (QASD) (Schienle et al., in print) } \\
\text { Brief Symptom Inventory (BSI: Derogatis, }\end{array}$ & $\begin{array}{l}\text { ANOVA (for } \\
\text { comparison across } \\
\text { groups) }\end{array}$ & $\begin{array}{l}\text { Self-disgust was elevated in the patient group. } \\
\text { Personal disgust was significantly higher than behavioural } \\
\text { disgust in the patient group but not in the control group. }\end{array}$ \\
\hline & $\begin{array}{l}\text { Are there any differences } \\
\text { across patient groups in } \\
\text { levels of self-disgust? } \\
\text { Is self-disgust (personal and } \\
\text { behavioural) related to } \\
\text { particular psychological traits } \\
\text { which confer vulnerability for } \\
\text { "mental disorder"? }\end{array}$ & & $\begin{array}{l}\text { personality } \\
\text { disorder, } \\
\text { schizophrenia, } \\
\text { depression, spider } \\
\text { phobia) compared } \\
\text { to } 112 \text { "healthy } \\
\text { controls". }\end{array}$ & 1993). & $\begin{array}{l}\text { Stepwise multiple } \\
\text { regression (for } \\
\text { examination of } \\
\text { relationship between } \\
\text { self-disgust and } \\
\text { specific symptoms). }\end{array}$ & $\begin{array}{l}\text { Patients with BPD and eating disorders had the highest levels } \\
\text { of self-disgust on both subscales. } \\
\text { In the patient group, hostility and psychoticism significantly } \\
\text { predicted personal disgust. Anxiety and interpersonal } \\
\text { sensitivity significantly predicted personal disgust. } \\
\text { Traumatic events during childhood were a significant risk } \\
\text { factor for self-disgust. }\end{array}$ \\
\hline $\begin{array}{ll}\text { Jones } & \text { et } \\
& \text { al. } \\
(2008) & \end{array}$ & $\begin{array}{l}\text { Impact of exudate and odour } \\
\text { from chronic venous leg } \\
\text { ulceration on anxiety and } \\
\text { depression. }\end{array}$ & $\begin{array}{l}\text { Hermeneutic } \\
\text { interviewing } \\
\text { (qualitative) }\end{array}$ & $\begin{array}{l}20 \text { people ( } 12 \\
\text { women, } 8 \text { men, } \\
\text { aged } 52-86, \\
\text { mean } 68 \text { years), } \\
\text { recruited from a } \\
\text { larger study, who } \\
\text { had experienced } \\
\text { chronic leg } \\
\text { ulcerations }\end{array}$ & Hermeneutic (unstructured) interviews & $\begin{array}{l}\text { Elements of Colazzi's } \\
(1978) \quad \text { framework } \\
\text { (examining significant } \\
\text { statements) and van } \\
\text { Manen's (1990) } \\
\text { structure (eliciting rich } \\
\text { descriptions of lived } \\
\text { experiences) }\end{array}$ & $\begin{array}{l}\text { Three themes: } \\
\text { Emotional responses to odour - disgust, revulsion, leading to } \\
\text { shame, embarrassment and self-loathing } \\
\text { Limitation on social activities due to odour or fear of odour } \\
\text { - due to a fear that others would find them disgusting } \\
\text { Way in which odour and fears of odour were managed } \\
\text { by nurses }\end{array}$ \\
\hline $\begin{array}{l}\text { Jung \& Steil } \\
(2013)\end{array}$ & $\begin{array}{l}\text { RCT evaluating the efficacy } \\
\text { of Cognitive Restructuring } \\
\text { and Imagery Modification } \\
\text { (CRIM) in treating Feeling of } \\
\text { Being Contaminated (FBC) } \\
\text { in PTSD }\end{array}$ & $\begin{array}{l}\text { Randomized } \\
\text { controlled trial }\end{array}$ & $\begin{array}{l}34 \text { women (mean } \\
\text { age 37) with } \\
\text { PTSD from CSA } \\
\text { were randomly } \\
\text { assigned to either } \\
\text { CRIM or wait-list } \\
\text { control }\end{array}$ & $\begin{array}{l}\text { Ratings of the intensity, vividness and } \\
\text { uncontrollability of and distress caused by the } \\
\text { FBC, pre, mid and post treatment. } \\
\text { Post-traumatic Diagnostic Scale (McCarthy, } \\
\text { 2008) } \\
\text { CAPS (Blake et al., 1995) } \\
\text { Administered pre and post-treatment and at } \\
\text { 4-week follow-up. }\end{array}$ & MANOVA & $\begin{array}{l}\text { Improvements in intensity of the FBC were significantly } \\
\text { larger in the CRIM group than in the FBC group. } \\
\text { A significantly larger reduction in PTSD severity was also } \\
\text { observed in the CRIM group relative to the wait-list group. }\end{array}$ \\
\hline
\end{tabular}




\begin{tabular}{|c|c|c|c|c|c|c|}
\hline $\begin{array}{l}\text { Jung \& Steil } \\
(2012)\end{array}$ & $\begin{array}{l}\text { Feeling of being } \\
\text { contaminated in adult } \\
\text { survivors of CSA and it's } \\
\text { treatment - a case study }\end{array}$ & $\begin{array}{l}\text { Case study } \\
\text { demonstrating } \\
\text { effectiveness of } \\
\text { 2session treatment } \\
\text { programme to } \\
\text { reduce FBC in } \\
\text { CSA-related } \\
\text { PTSD. }\end{array}$ & $\begin{array}{l}2 \text { women who } \\
\text { experienced } \\
\text { chronic } \\
\text { CSArelated PTSD } \\
\text { and } \\
\text { FBC }\end{array}$ & $\begin{array}{l}\text { CAPS (Blake et al., 1995) } \\
\text { Feeling of Being Contaminated scale ( } 4 \\
\text { questions assessing intensity, frequency, } \\
\text { distress and duration of FBC) }\end{array}$ & $\begin{array}{l}\text { Pre and post } \\
\text { intervention } \\
\text { comparison of means }\end{array}$ & $\begin{array}{l}\text { Qualitative description of the feeling of being contaminated } \\
\text { by participants } \\
\text { Significant reductions in PTSD symptoms following } \\
\text { treatment of the feeling of being contaminated }\end{array}$ \\
\hline $\begin{array}{l}\text { Laffan, Millar, } \\
\text { Salkovskis \& } \\
\text { Whitby (2015) }\end{array}$ & $\begin{array}{l}\text { Investigating perceptions of } \\
\text { disgust in older adults in } \\
\text { residential care homes. }\end{array}$ & $\begin{array}{l}\text { Cross-sectional } \\
\text { correlational }\end{array}$ & $\begin{array}{l}54 \text { older adults } \\
\text { (mean age 86) in } \\
\text { care homes vs } 21 \\
\text { older adults in the } \\
\text { community (mean } \\
\text { age 69) }\end{array}$ & $\begin{array}{l}\text { Patient Health Questionnaire (PHQ- } \\
\text { 9; Kroenke, Spitzer, and Williams, } \\
\text { 2001). } \\
\text { Specifically developed 9-item measure of } \\
\text { self-disgust and perceived-other disgust in } \\
\text { relation to care activities. }\end{array}$ & Mann-Whitney U & $\begin{array}{l}\text { Overall self-disgust and perceived-other disgust ratings were } \\
\text { very low in both samples. } \\
\text { No statistically significant relationships were found between } \\
\text { self-disgust or perceived other-disgust and depression in } \\
\text { either sample. }\end{array}$ \\
\hline Olatunji (2015) & $\begin{array}{l}\text { Does excessive engagement } \\
\text { in health-related behaviours } \\
\text { modulaterstable } \\
\text { disgustrelated variables, } \\
\text { including self-disgust? }\end{array}$ & $\begin{array}{l}\text { Between-groups } \\
\text { ABA design }\end{array}$ & $\begin{array}{l}60 \text { undergraduate } \\
\text { students ( } 30 \text { per } \\
\text { group; } 73 \% \\
\text { female in } 1 \text { group; } \\
80 \% \text { female in } \\
\text { another) }\end{array}$ & $\begin{array}{l}\text { Health behaviour checklist (HBC; Olatunji et } \\
\text { al., 2011) } \\
\text { Disgust scale-revised (DS-R; Haidt et al., } \\
\text { 1994) } \\
\text { SDS (Overton et al., 2008) } \\
\text { Manipulation task: Participants in the }\end{array}$ & A $2 \times 3$ ANCOVA & $\begin{array}{l}\text { A significant effect of time on disgust propensity was } \\
\text { observed in the experimental condition but not in the control } \\
\text { condition. } \\
\text { There was no significant reductions in self-disgust in either } \\
\text { the health-condition or control group over time. }\end{array}$ \\
\hline & & & & $\begin{array}{l}\text { experimental group monitored health } \\
\text { behaviours for } 1 \text { week (A), then engage in } \\
\text { excessive health-related behaviours (e.g. } \\
\text { washing, checking temperature) for } 1 \text { week } \\
\text { (B), then return to baseline and monitoring } \\
\text { (A). Controls - stage A only. }\end{array}$ & & \\
\hline $\begin{array}{l}\text { Olatunji, Cox \& } \\
\text { Kim (2015) }\end{array}$ & $\begin{array}{l}\text { Self-disgust mediates the } \\
\text { association between shame } \\
\text { and symptoms of bulimia and } \\
\text { OCD. }\end{array}$ & $\begin{array}{l}\text { Cross-sectional } \\
\text { correlational }\end{array}$ & $\begin{array}{l}403 \\
\text { undergraduates } \\
\text { (67\% women) }\end{array}$ & $\begin{array}{l}\text { Other As Shamer (Goss, Gilbert, \& } \\
\text { Allan,1994) } \\
\text { SDS (Overton et al., 2008) } \\
\text { Disgust Scale-Revised (Haidt et al., 1994) } \\
\text { Eating Attitudes Test—26 (EAT-26). } \\
\text { (Garner, Olmsted, } \\
\text { Bohr, \& Garfinkel, 1982) } \\
\text { Obsessive-Compulsive Inventory_-Revised } \\
\text { (OCI-R) (Foa et al., 2002) } \\
\text { DASS-21 (Lovibond \& Lovibond, 1993) }\end{array}$ & $\begin{array}{l}\text { Preacher \& Hayes } \\
(2008) \text { - } \\
\text { bootstrapping; linear } \\
\text { regressions }\end{array}$ & $\begin{array}{l}\text { Self-disgust mediated the relationship between shame and } \\
\text { OCD symptoms, as well as the relationship between shame } \\
\text { and bulimic symptoms. }\end{array}$ \\
\hline
\end{tabular}




\begin{tabular}{|c|c|c|c|c|c|c|}
\hline $\begin{array}{l}\text { Overton, } \\
\text { Markland, } \\
\text { Simpson, } \\
\text { Taggart \& } \\
\text { Bagshaw } \\
(2008)\end{array}$ & $\begin{array}{l}\text { Validation of the self-disgust } \\
\text { scale } \\
\text { Is the relationship between } \\
\text { dysfunctional attitudes and } \\
\text { depressive symptomatology } \\
\text { mediated by self-disgust? }\end{array}$ & $\begin{array}{l}\text { Cross-sectional } \\
\text { correlational }\end{array}$ & $\begin{array}{l}\text { A convenience } \\
\text { sample of } 111 \\
\text { participants }(81 \\
\text { females, } 30 \text { males) } \\
\text {, largely } \\
\text { comprising } \\
\text { undergraduate } \\
\text { students }\end{array}$ & $\begin{array}{l}\text { The Self-Disgust Scale (SDS) (Overton et } \\
\text { al., 2008) } \\
\text { The Beck Depression Inventory II (BDI-II) } \\
\text { (Beck, 1967) } \\
\text { The DASS-21 (Lovibond \& Lovibond, } \\
\text { 1993) } \\
\text { Dysfunctional Attitudes Scale - A } \\
\text { (Weissman, 1980) }\end{array}$ & $\begin{array}{l}\text { Factor analysis } \\
\text { Series of linear } \\
\text { regressions to conduct } \\
\text { Baron \& Kenny's } \\
\text { (1986) test for } \\
\text { mediation. }\end{array}$ & $\begin{array}{l}\text { The SDS demonstrated good psychometric properties, and } \\
\text { two underlying factors - disgusting "self" and disgusting } \\
\text { "ways". } \\
\text { Self-disgust partially mediated the relationship between } \\
\text { dysfunctional attitudes and depressive symptoms }\end{array}$ \\
\hline $\begin{array}{l}\text { Powell, Azlan, } \\
\text { Simpson \& } \\
\text { Overton (2016) }\end{array}$ & $\begin{array}{l}\text { Is the relationship between } \\
\text { disgust-related side effects } \\
\text { and depression mediated by } \\
\text { self-disgust in those high in } \\
\text { disgust sensitivity but not } \\
\text { low in disgust-sensitivity? }\end{array}$ & $\begin{array}{l}\text { Cross-sectional } \\
\text { correlational }\end{array}$ & $\begin{array}{l}132 \text { volunteers } \\
\text { who had been } \\
\text { treated for cancer } \\
\text { ( } 83 \text { women, mean } \\
\text { age } 57 \text { ) }\end{array}$ & $\begin{array}{l}\text { Disgust Propensity and Sensitivity } \\
\text { ScaleRevised (DPSSR; van Overveld et } \\
\text { al., 2006). SDS (Overton et al., 2008) } \\
\text { Hospital Anxiety and Depression Scale } \\
\text { (HADS; Zigmond \& Snaith, } 1983\end{array}$ & Path analysis & $\begin{array}{l}\text { Self-disgust mediated the relationship between } \\
\text { disgustrelated cancer side effects and depressive } \\
\text { symptomatology in those high in disgust-sensitivity but not } \\
\text { in those low in disgust-sensitivity. }\end{array}$ \\
\hline $\begin{array}{l}\text { Powell, } \\
\text { Overton \& } \\
\text { Simpson (2014) }\end{array}$ & $\begin{array}{l}\text { Qualitative exmploration of } \\
\text { the phenomenological } \\
\text { experience of self-disgust in } \\
\text { depression }\end{array}$ & $\begin{array}{l}\text { Semi-structured } \\
\text { interviews } \\
\text { (qualitative) }\end{array}$ & $\begin{array}{l}9 \text { female } \\
\text { participants (age } \\
19-39, \text { mean 24) } \\
\text { recruited from a } \\
\text { larger study who } \\
\text { scored high in self- } \\
\text { disgust (as } \\
\text { measured by the } \\
\text { SDS) and } \\
\text { depression (as } \\
\text { measured by the } \\
\text { DASS-21) }\end{array}$ & $\begin{array}{l}\text { Semi-structured interviews, in which } \\
\text { participants were informed that the purpose } \\
\text { of the interview was to examine disgust } \\
\text { towards the self. }\end{array}$ & $\begin{array}{l}\text { Interpretative } \\
\text { Phenomenological } \\
\text { Analysis }\end{array}$ & $\begin{array}{l}\text { Four themes: } \\
\text { Subjective experience of self-disgust }- \text { visceral, } \\
\text { allencompassing, can be experienced as an ever-present } \\
\text { background sense of a more intense emotional reaction } \\
\text { Origins of the disgusting self - disgust-based criticism or } \\
\text { abuse in childhood or adolescence. } \\
\text { Consequences of self-disgust - desire to cleanse the self, } \\
\text { strategies to deal with self-disgust (avoidance, withdrawal) } \\
\text { Self-disgust and other emotional states - hatred, anger, } \\
\text { shame, sadness }\end{array}$ \\
\hline $\begin{array}{l}\text { Powell, } \\
\text { Simpson \& } \\
\text { Overton (2013) }\end{array}$ & $\begin{array}{l}\text { Self-disgust should predict } \\
\text { depressive symptoms over } \\
\text { time, but not the reverse; } \\
\text { sixmonth self-disgust should } \\
\text { mediate the relationship } \\
\text { between dysfunctional } \\
\end{array}$ & $\begin{array}{l}\text { Repeated measures } \\
\text { longitudinal } \\
\text { design. }\end{array}$ & $\begin{array}{l}110 \text { participants } \\
\text { (final sample), } \\
77 \% \text { female }\end{array}$ & $\begin{array}{l}\text { Self-disgust scale (Overton et al., 2008) } \\
\text { Dysfunctional Attitudes Scale form A (DAS- } \\
\text { A; } \\
\text { Weissman, 1980). } \\
\text { Depression, Anxiety and Stress Scale } \\
\text { (DASS; Lovibond \& Lovibond, 1993). }\end{array}$ & $\begin{array}{l}\text { Structural equation } \\
\text { modelling }\end{array}$ & $\begin{array}{l}\text { Controlling for baseline depression, self-disgust at } 6 \text { months } \\
\text { predicted depression at } 12 \text { months; however, depression at } 6 \\
\text { months did not predict self-disgust at } 12 \text { months. } \\
\text { The effect of baseline dysfunctional attitudes on depression } \\
\text { at } 12 \text { months was mediated by } 6 \text {-month self-disgust. } \\
6 \text {-month self-disgust also significantly predicted } 12 \text {-month }\end{array}$ \\
\hline & $\begin{array}{l}\text { cognitions at baselines and } \\
\text { depression at } 12 \text { months }\end{array}$ & & & & & $\begin{array}{cl}\text { dysfunctional } & \text { attitudes, suggesting } \\
\text { more } & \text { circular relationship. }\end{array}$ \\
\hline
\end{tabular}




\begin{tabular}{|c|c|c|c|c|c|c|}
\hline $\begin{array}{l}\text { Nexiroglu, } \\
\text { Hickey \& } \\
\text { McKay (2010) }\end{array}$ & $\begin{array}{l}\text { The role of disgust in Body } \\
\text { Dysmorphic Disorder }\end{array}$ & $\begin{array}{l}\text { Repeated measures } \\
\text { (mirror trial) } \times 5) \\
\text { between groups } \\
\text { (x2 - BDD vs } \\
\text { control) design. }\end{array}$ & $\begin{array}{l}6 \text { participants }(5 \\
\text { male, } 1 \text { female) } \\
\text { with BDD vs } 8 \text { ( } 3 \\
\text { male, } 1 \text { female) } \\
\text { controls }\end{array}$ & $\begin{array}{l}\text { Disgust Scale-Revised (Haidt et al., } \\
\text { 1994) Physiological measures Visual } \\
\text { analogue scales. } \\
\text { Task - participants were asked to look in the } \\
\text { mirror and focus attention on a part of their } \\
\text { face they disliked. Ps were asked to report on } \\
\text { what they were focusing on. Ps then rated } \\
\text { how much disgust and anxiety they felt } \\
\text { whilst doing this task. This was repeated } 5 \\
\text { times. }\end{array}$ & $\begin{array}{l}\text { One-way repeated } \\
\text { measures ANOVAS. }\end{array}$ & $\begin{array}{l}\text { Significant decreases in disgust ratings over mirror trails in } \\
\text { the BDD group but not in the control group ( } \mathrm{n} 2=.49 \text { vs } \mathrm{n} 2= \\
\text {.16) } \\
\text { However, overall disgust ratings were much higher in the } \\
\text { BDD group (e.g. average of between } 40 \text { and } 55 \text { out of } 100 \\
\text { across trials, compared to average of between } 0 \text { and } 10 \\
\text { across trials for controls. }\end{array}$ \\
\hline $\begin{array}{ll}\text { Rusch } & \text { et } \\
& \text { al. } \\
(2011) & \end{array}$ & $\begin{array}{l}\text { Is there a stronger association } \\
\text { between the self and disgust } \\
\text { in those with BPD and PTSD } \\
\text { then between the self and } \\
\text { anxiety? }\end{array}$ & $\begin{array}{l}\text { Between-groups } \\
(2-\text { control vs dx }) \\
\text { design examining } \\
\text { differences in } \\
\text { responding to } \\
\text { implicit } \\
\text { association test. }\end{array}$ & $\begin{array}{l}20 \text { women with } \\
\text { BPD, } 20 \text { women } \\
\text { with PTSD, } 15 \\
\text { women with BPD } \\
\text { and PTSD, } 37 \\
\text { psychologically } \\
\text { healthy women. }\end{array}$ & $\begin{array}{l}\text { Implicit Association Test (IAT), measuring } \\
\text { response latencies when disgust or anxiety } \\
\text { words were associated with self or other }\end{array}$ & ANOVA & $\begin{array}{l}\text { Stronger relationship between disgust and the self than } \\
\text { between anxiety and the self in those with PTSD and BPD. }\end{array}$ \\
\hline $\begin{array}{l}\text { Schienle, } \\
\text { Leutgeb \& } \\
\text { Wabnegger } \\
(2015)\end{array}$ & $\begin{array}{l}\text { Are patients with BPD more } \\
\text { sensitive to disgusted facial } \\
\text { expressions in others? } \\
\text { Are patients with BPD higher } \\
\text { in self-disgust? } \\
\text { Is this associated with } \\
\text { abnormal activation in the } \\
\text { amygdala? }\end{array}$ & Case control & $\begin{array}{l}25 \text { women with a } \\
\text { BPD diagnosis, } \\
\text { and } 25 \text { healthy } \\
\text { women of } \\
\text { comparable age. }\end{array}$ & $\begin{array}{l}\text { Borderline Symptom List (BSL-23; } \\
\text { Bohus et al., 2009) } \\
\text { Questionnaire for the Assessment of Self- } \\
\text { Disgust (QASD) (Schienle et al., 2014) } \\
\text { Questionnaire for the Assessment of Disgust } \\
\text { Proneness } \\
\text { (QADP; Schienle et al., 2002) } \\
\text { T1 weighted brain scans (to enable } \\
\text { voxelbased morphology analysis). }\end{array}$ & 2-sample t-tests & $\begin{array}{l}\text { Borderline symptom-severity was positively correlated with } \\
\text { both personal and behavioural self-disgust }(\mathrm{r}=0.59 \text { and } \mathrm{r}= \\
0.53 \text { respectively). } \\
\text { The BPD group had significantly higher levels of selfdisgust. } \\
\text { Whole-brain analysis showed no significant between-group } \\
\text { differences, although there was increased grey matter } \\
\text { volume in the amygdala in the patient group. }\end{array}$ \\
\hline $\begin{array}{l}\text { Schienle, Haas- } \\
\text { Krammer, } \\
\text { Schoggle \& Ille } \\
\text { (2013) }\end{array}$ & $\begin{array}{l}\text { Altered state and trait disgust } \\
\text { in BPD }\end{array}$ & Case control & $\begin{array}{l}30 \text { female patients } \\
\text { with BPD } \\
\text { compared with } 30 \\
\text { healthy women. }\end{array}$ & $\begin{array}{l}\text { Borderline Symptom List (BSL-23; } \\
\text { Bohus et al., 2009) } \\
\text { Questionnaire for the Assessment of Disgust } \\
\text { Proneness } \\
\text { (QADP; Schienle et al., 2002) } \\
\text { Scale for the Assessment of Disgust } \\
\text { Sensitivity (SADS; } \\
\text { Schienle et al., 2010) } \\
\text { Questionnaire for the Assessment of } \\
\text { SelfDisgust (QASD) }\end{array}$ & $\begin{array}{l}\text { Correlation matrix } \\
\text { One-way ANOVA }\end{array}$ & $\begin{array}{l}\text { Elevated levels of self-disgust were reported in the BPD } \\
\text { group - significantly higher than in the control group. } \\
\text { Significant correlations were observed between self-disgust } \\
\text { and borderline symptom severity in the patient group ( } \mathrm{r}= \\
.67 \text {, personal disgust; } \mathrm{r}=.51 \text {, behavioural disgust). }\end{array}$ \\
\hline $\begin{array}{l}\text { Simpson, } \\
\text { Hillman, } \\
\text { Crawford \& } \\
\text { Overton }(2010)\end{array}$ & $\begin{array}{l}\text { Does self-esteem and } \\
\text { selfdisgust independently } \\
\text { mediate the relationship } \\
\text { between dysfunctional } \\
\text { cognitions and depression? }\end{array}$ & $\begin{array}{l}\text { Cross-sectional } \\
\text { correlational }\end{array}$ & $\begin{array}{l}\text { Non-clinical } \\
\text { sample of } 110 \\
\text { participants }(84 \\
\text { females, } 36 \text { males, } \\
\text { mean age 21) }\end{array}$ & $\begin{array}{l}\text { Self-Disgust Scale (Overton et al., 2008) } \\
\text { BDI-II (Beck, 1967) } \\
\text { DASS (Lovibond \& Lovibond, } \\
\text { 1993) DAS-A (Weissman, 1980). } \\
\text { Rosenberg self-esteem }\end{array}$ & $\begin{array}{l}\text { Baron \& Kenny (1986) } \\
\text { - series of linear } \\
\text { regression models. }\end{array}$ & $\begin{array}{l}\text { Both self-disgust and self-esteem independently partially } \\
\text { mediated the relationship between dysfunctional attitudes } \\
\text { and depression. }\end{array}$ \\
\hline
\end{tabular}




\begin{tabular}{|c|c|c|c|c|c|c|}
\hline $\begin{array}{l}\text { Smith, Steil, } \\
\text { Weitzman, }\end{array}$ & $\begin{array}{l}\text { Does self-disgust mediate the } \\
\text { relationship between }\end{array}$ & Cross-sectional & $\begin{array}{l}549 \text { undergraduate } \\
\text { psychology }\end{array}$ & $\begin{array}{l}\text { Inventory of Statements about } \\
\text { Self-Injury (ISAS; Klonsky \& Glenn, }\end{array}$ & $\begin{array}{l}\text { Baron \& Kenny } \\
(1986) \text { - series of }\end{array}$ & $\begin{array}{l}\text { Self-disgust fully mediated the relationship between } \\
\text { depression and non-suicidal self-injury. }\end{array}$ \\
\hline $\begin{array}{l}\text { Trueba \& } \\
\text { Meuret (2015) }\end{array}$ & $\begin{array}{l}\text { depression and Non-Suicidal } \\
\text { Self-Injury (NSSI)? } \\
\text { Does self-disgust mediate the } \\
\text { relationship between Child } \\
\text { Sexual Abuse and NSSI? }\end{array}$ & & students & $\begin{array}{l}2009) \\
\text { Self-disgust scale (Overton et al., 2008) } \\
\text { Depression Anxiety Stress Scale } \\
\text { (DASS; Lovibond \& Lovibond, 1995) } \\
\text { Painful and Provocative Events Scale } \\
\text { (Bender, Gordon, Bresin et al., 2011). }\end{array}$ & linear regressions. & $\begin{array}{l}\text { Self-disgust partially mediated the relationship between } \\
\text { childhood sexual abuse and non-suicidal self-injury. }\end{array}$ \\
\hline $\begin{array}{l}\text { Steil, Jung \& } \\
\text { Stangier (2011) }\end{array}$ & $\begin{array}{l}\text { Pilot study evaluating } \\
\text { efficacy of specially } \\
\text { developed intervention in } \\
\text { treating FBC in PTSD }\end{array}$ & $\begin{array}{l}\text { Single-group } \\
\text { repeated measures } \\
\text { design assessing } \\
\text { outcomes before } \\
\text { and after } \\
\text { treatment and at } \\
\text { follow-up. }\end{array}$ & $\begin{array}{l}9 \text { women (age } 28 \\
-57 \text {, mean age } 43 \text { ) } \\
\text { suffering from } \\
\text { chronic } \\
\text { CSArelated PTSD } \\
\text { plus the FBC. }\end{array}$ & $\begin{array}{l}\text { Ratings of the intensity, vividness and } \\
\text { uncontrollability of and distress caused by the } \\
\text { FBC, pre, mid and post treatment. } \\
\text { Post-traumatic Diagnostic Scale. } \\
\text { CAPS (Blake et al., 1995) }\end{array}$ & $\begin{array}{l}\text { Wilcoxon's test for } \\
\text { post-hoc comparison } \\
\text { between means. }\end{array}$ & $\begin{array}{l}\text { Large reductions in FBC between } \mathrm{t} 0 \text { and } \mathrm{t} 2(\mathrm{~d}=2.23) \text { and in } \\
\text { PDS scores }(\mathrm{d}=0.99) \text {. } \\
\text { Large reductions in PTSD symptoms. }\end{array}$ \\
\hline
\end{tabular}


Appendix A Effect sizes for the relationship between selfdisgust and depression

\begin{tabular}{|c|c|c|}
\hline Study & $\begin{array}{l}\text { Zero-order } \\
\text { correlation }\end{array}$ & $\begin{array}{l}\text { Partial correlations/ } \\
\text { Beta value }\end{array}$ \\
\hline $\begin{array}{l}\text { Azlan et al. (2017) } \\
\text { Physical self-disgust } \\
\text { Behavioural self-disgust } \\
\text { Controlling for disgust sensitivity and disgust propensity: } \\
\text { Physical self-disgust } \\
\text { Behavioural self-disgust }\end{array}$ & $\begin{array}{l}r=.64 \\
r=.53\end{array}$ & $\begin{array}{l} \\
\beta=.60 \text { (cancer), } \beta=.54 \\
(\text { control) } \\
\beta=.08 \text { (cancer), } \beta=.12 \\
\text { (control) }\end{array}$ \\
\hline $\begin{array}{l}\text { Overton et al. (2008) } \\
\text { Controlling for dysfunctional cognitions }\end{array}$ & $r=.66$ & $\beta=.61$ \\
\hline $\begin{array}{l}\text { Simpson et al. (2010) } \\
\text { Unique contribution relative to low self-esteem }\end{array}$ & $\mathrm{r}=.47$ & 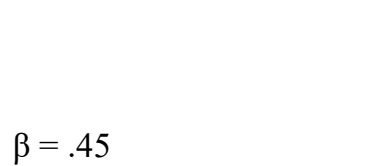 \\
\hline $\begin{array}{l}\text { Powell et al. (2013) } \\
\text { Controlling for dysfunctional cognitions, unique contribution } \\
\text { at } 6 \text { months } \\
\text { Controlling for dysfunctional cognitions, unique contribution } \\
\text { at } 12 \text { months }\end{array}$ & $\mathrm{r}=.51$ & $\begin{array}{l}\beta=.30 \\
\beta=.26\end{array}$ \\
\hline $\begin{array}{l}\text { Powell et al. (2016) (physical, behavioural) } \\
\text { Physical self-disgust } \\
\text { Behavioural self-disgust }\end{array}$ & $\mathrm{r}=.72, \mathrm{r}=.60$ & $\begin{array}{l}\beta=.47 \\
\beta=.26\end{array}$ \\
\hline $\begin{array}{l}\text { Laffan et al. (2015) - no effect sizes reported for the } \\
\text { relationship between self-disgust and depression. }\end{array}$ & non-significant & \\
\hline
\end{tabular}


Ille et al. (2014)

Personal disgust

Behavioural disgust

$r=.335$

ns - not

reported

Appendix B Effect sizes for the relationship between selfdisgust and anxiety

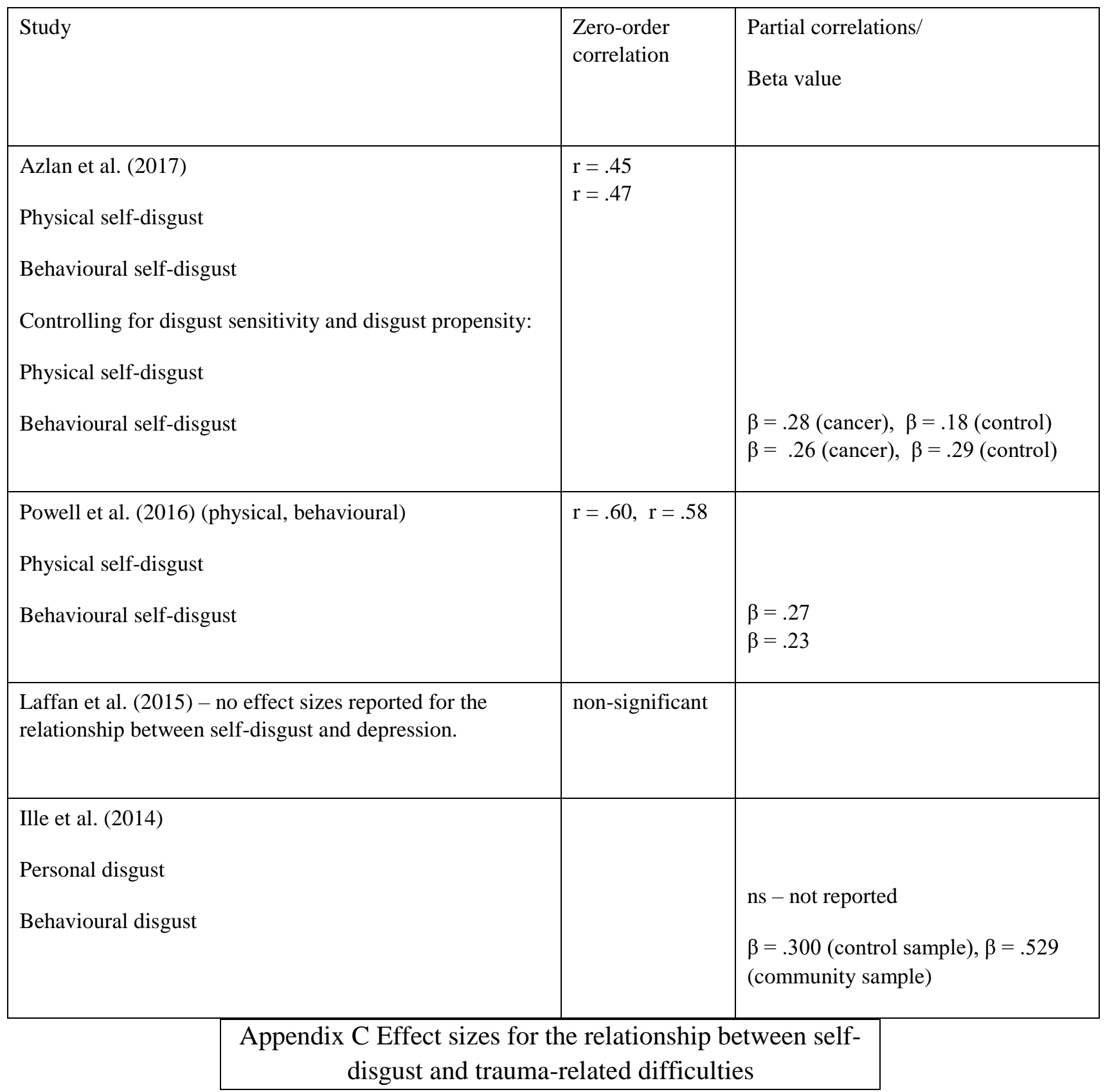




\begin{tabular}{|c|c|c|}
\hline Study & $\begin{array}{l}\text { Zero-order } \\
\text { correlation }\end{array}$ & $\begin{array}{l}\text { Partial corr/ } \\
\text { Beta value }\end{array}$ \\
\hline $\begin{array}{l}\text { Badour et al. (2014)-relationship between self-disgust and mental contamination } \\
\text { after trauma } \\
\text { Controlling for post-traumatic cognitions, depression, physical contamination fears, } \\
\text { PTSD dx }\end{array}$ & $\mathrm{r}=.48$ & $\beta=.34$ \\
\hline $\begin{array}{l}\text { Badour et al. (2012) - peri-traumatic self-disgust and PTSD symptoms } \\
\text { Controlling for disgust sensitivity, obsessive-compulsive symptoms, anxiety } \\
\text { sensitivity, negative affect. }\end{array}$ & $\mathrm{r}=.07$ & $\beta=-.07$ \\
\hline $\begin{array}{l}\text { Badour et al. (2013) - relationship between mental contamination following trauma } \\
\text { and PTSD } \\
\text { Controlling for disgust-sensitivity }\end{array}$ & $\mathrm{r}=.66$ & $\beta=.54$ \\
\hline Brake et al. (2017) - reported unstandardized estimates only & & \\
\hline Dyer et al. (2015) - effect sizes not reported. & & \\
\hline $\begin{array}{l}\text { Rusch et al. (2011) - compared the association between the self and disgust in } \\
\text { PTSD\&BPD women (0) and healthy controls (1) }\end{array}$ & $r=-.34$ & \\
\hline $\begin{array}{l}\text { Bowyer et al. (2011) - case study; reduction in PTSD symptoms after a self-disgust } \\
\text { based intervention - not reported }\end{array}$ & & \\
\hline $\begin{array}{l}\text { Jung \& Steil (2012) - case study examining reduction in PTSD symptoms after } \\
\text { selfdisgust focused intervention - no effect size reported }\end{array}$ & & \\
\hline $\begin{array}{l}\text { Steil, Jung \& Stangier (2011) - small scale pilot study examining reduction in PTSD } \\
\text { symptoms after self-disgust focused intervention. }\end{array}$ & $\mathrm{r}=.44$ & \\
\hline $\begin{array}{l}\text { Jung \& Steil (2013) - RCT examining reduction in PTSD symptoms after selfdisgust } \\
\text { focused intervention - effect size indicates difference in PTSD symptoms over time } \\
\text { in treatment group as compared to the control group. }\end{array}$ & $\mathrm{r}=.42$ & \\
\hline
\end{tabular}




\begin{tabular}{|c|c|c|c|}
\hline & $\begin{array}{c}\text { Appendix D } \\
\text { Effect sizes for the relationship between sel } \\
\text { body-image difficulties }\end{array}$ & disgust and & \\
\hline \multicolumn{2}{|l|}{ Study } & $\begin{array}{l}\text { Zero-order } \\
\text { correlation }\end{array}$ & Beta value \\
\hline \multicolumn{4}{|c|}{$\begin{array}{l}\text { Bornholt et al. (2005) - comparison of disgust-related words circled in a } \\
\text { body-focus task between anorexic girls and a control group - effect sizes not } \\
\text { reported. }\end{array}$} \\
\hline \multicolumn{4}{|c|}{$\begin{array}{l}\text { Neziroglu et al. (2010) - comparison of people with BDD to controls on a } \\
\text { visual analogue self-disgust after mirror task - effect sizes not reported, but } \\
\text { raw between-group data suggest large differences [50/100 (BDD) compared } \\
\text { to } 10 / 100 \text { (controls)] }\end{array}$} \\
\hline $\begin{array}{l}\text { Chu et al. (2015) }-\mathrm{r} \\
\text { relationship between } \\
\text { Controlling for anxie } \\
\text { Relationship betwee } \\
\text { Relationship betwee } \\
\text { Relationship betwee } \\
\text { Relationship betwee } \\
\text { Relationship betwee } \\
\text { Relationship betwee } \\
\text { in those high in self- }\end{array}$ & $\begin{array}{l}\text { tionship between suicidality and self-disgust } \\
\text { and-disgust and eating disorder symptoms } \\
\text { and depression: } \\
\text { elf-disgust and suicidal ideation } \\
\text { elf-disgust and bulimia } \\
\text { elf-disgust and body dissatisfaction } \\
\text { elf-disgust and drive for thinness } \\
\text { elf-disgust*eating disorder and suicidal ideation } \\
\text { hose eating disorder symptoms and suicidal ideation } \\
\text { gust }\end{array}$ & $\begin{array}{l}\mathrm{r}=.34 \\
\mathrm{r}=.51\end{array}$ & $\begin{array}{l}\beta=0.14 \\
\beta=0.06 \\
\beta=0.30 \\
\beta=0.25 \\
\beta=0.14 \\
\beta=0.23\end{array}$ \\
\hline $\begin{array}{l}\text { Olatunji et al. (2015) } \\
\text { bulimia } \\
\text { Controlling for sham } \\
\text { Controlling for sham }\end{array}$ & $\begin{array}{l}\text { relationship between self-disgust and symptoms of } \\
\text { (unique contribution): } \\
\text { (added contribution) }\end{array}$ & $\mathrm{r}=.24$ & $\begin{array}{l}\beta=.14 \\
\beta=.02\end{array}$ \\
\hline $\begin{array}{l}\text { Ille et al. (2014) - cc } \\
\text { healthy controls on } \mathrm{s} \\
\text { Personal disgust: } \\
\text { Behavioural disgust: }\end{array}$ & $\begin{array}{l}\text { parison of people with eating disorders compared to } \\
\text {-disgust }\end{array}$ & $\begin{array}{l}\mathrm{r}=.561 \\
\mathrm{r}=.548\end{array}$ & \\
\hline
\end{tabular}


Appendix E Effect sizes for the relationship between selfdisgust and self-harm

\begin{tabular}{|l|l|l|}
\hline Study & $\begin{array}{l}\text { Zero-order } \\
\text { correlation }\end{array}$ & $\begin{array}{l}\text { Partial } \\
\text { correlations/ } \\
\text { Beta value }\end{array}$ \\
\hline Bachtelle \& Pepper (2015) - scar-related shame and self-disgust & $\begin{array}{l}\mathrm{r}=.64 \\
\mathrm{r}=-.49\end{array}$ & \\
\hline Smith et al. (2015) - standardised effect sizes not reported & & \\
\hline Abdul-Hamid et al. (2014) - effect sizes not reported. & & \\
\hline
\end{tabular}


Appendix F Effect sizes for the relationship between selfdisgust and obsessive-compulsive difficulties

\begin{tabular}{|l|l|l|}
\hline Study & $\begin{array}{l}\text { Zero-order } \\
\text { correlation }\end{array}$ & $\begin{array}{l}\text { Partial correlation/ } \\
\text { Beta value }\end{array}$ \\
\hline $\begin{array}{l}\text { Badour et al. (2012) - relationship between peritraumatic self-focused } \\
\text { disgust and o/c symptoms } \\
\begin{array}{l}\text { Controlling for disgust sensitivity, anxiety sensitivity, post-traumatic } \\
\text { symptoms, depression }\end{array}\end{array}$ & $\mathrm{r}=.38$ & $\beta=0.02$ \\
\hline $\begin{array}{l}\text { Olatunji et al. (2015) - relationship between self-disgust and o/c } \\
\text { symptoms }\end{array}$ & $\mathrm{r}=.30$ & $\beta=.12$ \\
\hline Controlling for shame & $\begin{array}{l}\text { Olatunji et al. (2014) - effect of engaging in excessive health-related } \\
\text { behaviours on self-disgust - no significant effect }\end{array}$ & \\
\hline
\end{tabular}


Appendix G Effect sizes for the relationship between selfdisgust and borderline personality difficulties

\begin{tabular}{|c|c|c|}
\hline Study & $\begin{array}{l}\text { Zero-order } \\
\text { correlation }\end{array}$ & $\begin{array}{l}\text { Partial correlations/ } \\
\text { Beta value }\end{array}$ \\
\hline Dudas et al. (2017) - no effect size reported & & \\
\hline $\begin{array}{l}\text { Schienle et al. (2015) - relationship between "borderline } \\
\text { symptoms" and personal self-disgust } \\
\text { Relationship between "borderline symptoms" and } \\
\text { behavioural self-disgust }\end{array}$ & $\begin{array}{l}\mathrm{r}=.59 \\
\mathrm{r}=.53\end{array}$ & \\
\hline $\begin{array}{l}\text { Schienle et al. (2013) - relationship between BPD, } \\
\text { selfdisgust and amygdala structure - no effect sizes reported }\end{array}$ & & \\
\hline Ille et al. (2014) & $\mathrm{r}=.64$ & \\
\hline
\end{tabular}


Role of Funding Sources: The project was undertaken as part of a doctoral research project supported by internal funds of the Universities of Lancaster and Manchester. The authors did not receive any external funds to support this work.

Contributions: All three authors developed the review protocol. AC led on the database searches, study selection, data extraction and initial data analyses. All three authors contributed to the decisions around study selection, interpretation of the review findings and the write-up of the review.

Conflicts of Interest: The authors declare no conflicts of interest. 
